\title{
Stem Cell Therapy for Ischemic Heart Disease
}

\author{
Mohammad Nurulqadr Jameel and Jianyi Zhang
}

\begin{abstract}
Stem cell transplantation has emerged as a novel treatment option for ischemic heart disease. Different cell types have been utilized and the recent development of induced pluripotent stem cells has generated tremendous excitement in the regenerative field. Bone marrow-derived multipotent progenitor cell transplantation in preclinical large animal models of postinfarction left ventricular remodeling has demonstrated long-term functional and bioenergetic improvement. These beneficial effects are observed despite no significant engraftment of bone marrow cells in the myocardium and even lower differentiation of these cells into cardiomyocytes. It is thought to be related to the paracrine effect of these stem cells, which secrete factors that lead to long-term gene expression changes in the host myocardium, thereby promoting neovascularization, inhibiting apoptosis, and stimulating resident cardiac progenitor cells. Future studies are warranted to examine the changes in the recipient myocardium after stem cell transplantation and to investigate the signaling pathways involved in these effects. Antioxid. Redox Signal. 13, 1879-1897.
\end{abstract}

\section{Introduction}

A PPROXIMATEly $45 \%$ of PATIENTS with coronary artery disease go on to develop congestive heart failure despite state-of-the-art coronary interventions and medical therapy (147). Cardiac transplantation is the only treatment option available for replacing the lost muscle, but it is limited by the inadequate supply of donor hearts. Stem cell transplantation provides a unique therapeutic strategy to limit postinfarction left ventricle (LV) remodeling and the consequent development of congestive heart failure.

Recent studies have provided evidence that cardiomyocyte regeneration may occur during physiological and pathological states in the heart; these data highlight the possibilities that myocardial regeneration may occur via cardiomyocyte proliferation or proliferation and differentiation of putative cardiac stem cells (CSCs) (6). Bone marrow (BM)-derived multipotent progenitor cell (MPC) transplantation in a porcine model of postinfarction left ventricular remodeling leads to an improvement in ejection fraction and myocardial energetic at 4 months after myocardial infarction (45). This is associated with a decrease in left ventricular hypertrophy, amelioration of left ventricular dilatation, and decrease in scar size despite minimal engraftment of stem cells. It is postulated that these beneficial effects are related to induction of host myocardium gene expression changes, which included a downregulation of mitochondrial oxidative enzymes and upregulation of myocyte enhancer factor 2a (MEF2a) and ZFP91 (a member of the zinc finger family of proteins associated with ciliary neurotrophic factor) (45).

Many different cell types have been used for cardiac repair, including skeletal myoblasts, BM-derived cells, endothelial progenitor cells (EPCs), umbilical cord blood (UCB) stem cells, CSCs, embryonic stem cells (ESCs), and induced pluripotent stem cells (see Table 1 for summary of cell types). This article will review each of these different stem cell types in regard to treatment of ischemic heart disease.

\section{Cells for Myocardial Repair in Ischemic Heart Disease}

\section{Skeletal myoblasts}

Skeletal myoblasts are derived from satellite cells that lie in a quiescent state under the basal lamina of skeletal muscle fibers and are rapidly mobilized, proliferate, and fuse to repair muscle after an injury (136). Skeletal myoblasts form viable, long-term skeletal myotube grafts after transplantation into adult hearts (58). Transplantation of autologous skeletal myoblasts in cryoinfarcted rabbit myocardium leads to myoblast engraftment at 3 weeks with subsequent improvement in systolic performance (136). In another study, implanted skeletal myoblasts form viable grafts in infarcted rat myocardium, resulting in enhanced post-myocardial infarction (MI) exercise capacity and contractile function and attenuated ventricular dilation (44). He

Department of Medicine, University of Minnesota Medical School, Minneapolis, Minnesota. 
Table 1. Comparison of Different Cell Types for Cardiac Repair

\begin{tabular}{|c|c|c|}
\hline Cell type & Advantages & Disadvantages \\
\hline Skeletal myoblasts & $\begin{array}{l}\text { Easiness of procurement } \\
\text { Autologous source } \\
\text { In vitro scalability } \\
\text { Lack of serious concerns } \\
\text { about tumoriginicity } \\
\text { Resistance to ischemia }\end{array}$ & $\begin{array}{l}\text { Inability to establish functional electromechanical } \\
\text { connections with the host cardiomyocytes } \\
\text { Increased risk of arrhythmias } \\
\text { Lack of differentiation into cardiomyocytes }\end{array}$ \\
\hline Bone marrow stem cells & $\begin{array}{l}\text { Autologous source } \\
\text { Induces angiogenesis }\end{array}$ & Limited ability to differentiate into cardiomyocytes \\
\hline Mesenchymal stem cells & $\begin{array}{l}\text { Avoid rejection by } \\
\text { being hypoimmmunogenic } \\
\text { Easily accessible and expandable } \\
\text { Off-the-shelf allogeneic } \\
\text { product possible } \\
\text { Induces angiogenesis }\end{array}$ & Limited ability to differentiate into cardiomyocytes \\
\hline $\begin{array}{l}\text { Endothelial } \\
\text { progenitor cells }\end{array}$ & $\begin{array}{l}\text { Autologous source } \\
\text { Induces angiogenesis }\end{array}$ & Cannot differentiate into cardiomyocytes \\
\hline $\begin{array}{l}\text { Umbilical cord } \\
\text { blood stem cells }\end{array}$ & Autologous source & $\begin{array}{l}\text { Limited supply } \\
\text { Unclear whether these cells can differentiate } \\
\text { into cardiomyocytes }\end{array}$ \\
\hline Cardiac stem cells & $\begin{array}{l}\text { Cardiomyocyte phenotype } \\
\text { with no need for differentiation } \\
\text { Can integrate with host cardiomyocyte } \\
\text { Autologous transplantation }\end{array}$ & $\begin{array}{l}\text { Very limited supply } \\
\text { Difficult to isolate and propagate in culture } \\
\text { Proarrhythmic risk due to immature phenotype } \\
\text { of derived cardiomyocyte }\end{array}$ \\
\hline Embryonic stem cells & $\begin{array}{l}\text { Pluripotent and unlimited supply } \\
\text { Patient-specific cells for autologous } \\
\text { transplantation possible via } \\
\text { therapeutic cloning }\end{array}$ & $\begin{array}{l}\text { Social and ethical concerns } \\
\text { Limited supply of human oocytes } \\
\text { Risk of tumor formation } \\
\text { Proarrhythmic risk due to immature } \\
\text { phenotype of derived cardiomyocyte }\end{array}$ \\
\hline $\begin{array}{l}\text { Induced pluripotent } \\
\text { stem cells }\end{array}$ & $\begin{array}{l}\text { Pluripotent and unlimited supply } \\
\text { Patient-specific cells for autologous } \\
\text { transplantation possible }\end{array}$ & $\begin{array}{l}\text { Risk of tumor formation } \\
\text { Risk of viral vector } \\
\text { Proarrhythmic risk due to immature } \\
\text { phenotype of derived cardiomyocyte }\end{array}$ \\
\hline
\end{tabular}

et al. have shown a significant left- and upward shift of the endsystolic pressure-endsystolic volume relationship 10 weeks after transplantation of autologous skeletal myoblasts in a dog model of chronic heart failure (37). Transplantation of preconditioned skeletal myoblasts (treated for $30 \mathrm{~min}$ with $200 \mu \mathrm{M}$ diazoxide) resulted in greater survival of transplanted cells and caused a significantly higher improvement of ventricular function in a rat model of myocardial infarction, which was thought to be related to paracrine factors that promote angiomyogenesis $(33,97)$.

Skeletal myoblasts have several advantages in terms of cell transplantation for cardiac repair. First, these cells have an autologous origin making accessibility easy and avoiding any immune rejection. Second, they have a high degree of scalability in culture (one billion cells can be yielded from an initial small biopsy over a 2-3-week time frame). Third, these cells have a high resistance to ischemia, resulting in improved survival in infarct and peri-infarct regions. Lastly, as these cells are terminally differentiated, they do not form tumors.

However, being myogenic committed, they do not have the ability to differentiate into cardiomyocytes (28). Skeletal myoblasts also have differing electrical properties and their transplantation has been linked to increased risk of arrhythmias. Cardiomyocytes are electromechanically coupled by specialized cell-cell junctions, the intercalated disks, which contain adherens (N-cadherin), and gap junctions (connexin 43) for mechanical and electrical coupling, respectively. Electromechanical coupling between cardiomyocytes is a basic requirement for coordinated mechanical activity in myocardium. In contrast to heart muscle cells, skeletal muscle fibers are electrically isolated from one another, a prerequisite for fine motor control. Reinecke et al. showed that differentiated skeletal muscle grafts in injured hearts had no detectable $\mathrm{N}$-cadherin or connexin 43; hence, electromechanical coupling did not occur after in vivo grafting (113). In vitro cardiomyocytes can form electromechanical junctions with some skeletal myotubes in coculture and induce their synchronous contraction via gap junctions (113). However, in vivo skeletal myoblasts are not electromechanically coupled to each other or to surrounding cardiomyocytes (67). Myoblast-associated reentrant arrhythmias can be significantly reduced and efficacy increased by genetically making these cells overexpress connexin $43(2,114)$. 


\section{BM-derived stem cells}

It is still debated in literature whether BM-derived cells differentiate into cardiomyocytes. Bittner et al. were the first to suggest that cardiac muscle cells may be derived from BM cells (18). Goodell and coworkers showed that after transplantation of murine BM side population (SP) cells (cytokine receptor that binds to stem cell factor [c-kit+], Sca-1+, and CD34-/low), donor-derived cells with cardiomyocyte morphology, as well as smooth muscle and endothelial cells were found in the heart after left anterior descending (LAD) ligation (43). Orlic et al. (102) showed that transplantation of green fluorescent protein-positive (GFP+) Lin-c-kit+ cells (presumably containing both hematopoietic stem cells [HSC] and mesenchymal stem cells) into the ventricular wall after LAD ligation resulted in improved function of the ventricle and they detected a large number of GFP+ cells with cardiac phenotype in the myocardium. In contrast to these finding, other laboratories using genetic techniques showed that lineage-negative, c-kit + cells did not differentiate into cardiomyocytes $(10,92)$. However, more recently, Anversa and colleagues have shown using similar genetic techniques that c-kit + BM cells can engraft in the proximity to the infarcted myocardium and differentiate into cells of the cardiogenic lineage, forming functionally competent cardiomyocytes and vascular structures (115).

It was Caplan's group in the late 1980s and in the 1990s who identified a subset of cells within the BM that gave rise to osteoblasts and adipocytes and termed them mesenchymal stem cells (MSCs) (19). MSCs are present in many different organs of the body, including muscle, skin, adipose tissue, and BM. They can be isolated from the BM by a simple process involving Ficoll centrifugation and adhering-cell culture in defined serum-containing medium. MSCs can be expanded for 4-20 population doublings only (111) with preservation of the karyotype, telomerase activity, and telomere length (108, 109). Phenotypically, these cells are negative for CD31, CD34, and CD 45, unlike hematopoietic progenitors from BM, and are positive for CD29, CD44, CD71, CD90, CD105, CD106, CD120a, CD124, SH2, SH3, and SH4 $(36,76,110)$. In the BM, only $0.001 \%-0.01 \%$ of the initial unfractionated BM mononuclear cell population consists of MSCs $(110,111)$. However, in many recent rodent studies, the adherent fibroblastic cells obtained from the unfractionated mononuclear class of the BM are termed MSCs $(3,87)$.

MSCs have been reported to have the potential to differentiate into any tissue of mesenchymal origin (19). MSCs derived from rodent marrow aspiration have been shown to differentiate into cardiomyocytes in the presence of 5aza-cytidine $(30,77)$. The morphology of the cells changes from spindle-shaped to ball-shaped and finally rod-shaped form. Thereafter, these cells fuse together to form a syncytium, which resembles a myotube (31). These exhibit markers of fetal cardiomyocytes (77). Specific transcription factors of the myocyte and cardiac lineage, including GATA4, Nkx2.5, and HAND 1/2, can be detected (30). There are differences (as compared to native cardiomyocytes) in cardiomyocytes derived from MSCs. First, $\beta$-isoform of cardiac myosin heavy chain is more abundant than the $\alpha$-isoform in these cells. Second, there is more $\alpha$-skeletal actin than $\alpha$-cardiac actinin, and myosin light chain $2 \mathrm{v}$ is also present. Third, MEF2a and $\mathrm{MEF} 2 \mathrm{~d}$ replace $\mathrm{MEF} 2 \mathrm{c}$ isoforms from early to late passage.
These cells beat spontaneously and synchronously, which is most likely due to the formation of intercalated discs, as has been shown when they are cocultured with neonatal myocytes (139). They express competent $\alpha$ - and $\beta$-adrenergic and muscarinic receptors as indicated by an increased rate of contraction in response to isoproterenol and a decreased rate of contraction induced by $\beta$-adrenergic blockers (34). This in vitro differentiation to myocytes has been replicated using MSCs from pig BM-derived MSCs (72).

MSCs have features that make them attractive candidates for cell transplantation. As they are easily accessible and expandable, MSCs could potentially become an off-the-shelf allogeneic product that would be more cost effective, easier to administer, allow greater number of cells to be transplanted, and, possibly of importance, permit transplantation at the time of urgent interventions to relieve ischemia and injury such as percutaneous or surgical revascularization procedures. Importantly, these cells appear to avoid rejection by being hypoimmunogenic $(12,66,141)$. These cells lack major histocompatibility complex (MHC)-II and B-7 costimulatory molecule expression and thus limit T-cell responses $(117,160)$. They can also directly inhibit inflammatory responses via paracrine mechanisms, including production of transforming growth factor $\beta 1$ and hepatocyte growth factor (HGF) $(26,65)$. All the above properties make them potentially excellent candidates for cell transplantation.

MSC transplantation was tested in a study in which isogenic adult rats were used as donors and recipients to simulate autologous transplantation clinically. MSC intracoronary injection in these rat hearts after myocardial infarction showed mileu-dependent differentiation of these cellsfibroblastic phenotype within the scar and cardiomyocyte phenotype outside the infarction area (144). However, direct intramyocardial injection of autologous MSC into the scar resulted in differentiation into cardiac-like muscle cells within the scar tissue, induced angiogenesis, and improved myocardial function (138). Delivery of MSC via direct left ventricular cavity infusion in a rat myocardial infarction model resulted in preferential migration and colonization of the cells in the ischemic myocardium at 1 week (11). MSCs also resulted in increased vascularity and improved cardiac function at 2 months in a canine model of chronic ischemic disease (120). However, Kloner's group using a rat model of postinfarction LV remodeling found that the beneficial effects on left ventricular function were short term and were absent after 6 months (24).

Our group has studied the outcome of BM-derived MPCs in large animal models of myocardial infarction. We performed intramyocardial transplantation of allogeneic MSCs in a porcine model of myocardial infarction that resulted in a profound improvement in borderzone energetic, regional, and global contractile function (157). Only $0.35 \% \pm 0.05 \%$ donor cells could be detected 4 weeks after left anterior descending artery ligation, independent of cell transplantation with or without immunosuppression with cyclosporine A (157). The fraction of grafted cells that acquired an endothelial or cardiomyocyte phenotype was $3 \%$ and $\sim 2 \%$, respectively (Fig. 1). Patchy spared myocytes in the infarct zone were found only in stem cell-transplanted hearts (Fig. 1). As the engraftment rate was low, the beneficial effects were thought to be related to paracrine mechanisms as evidenced by increased vascularity in the borderzone and spared native 

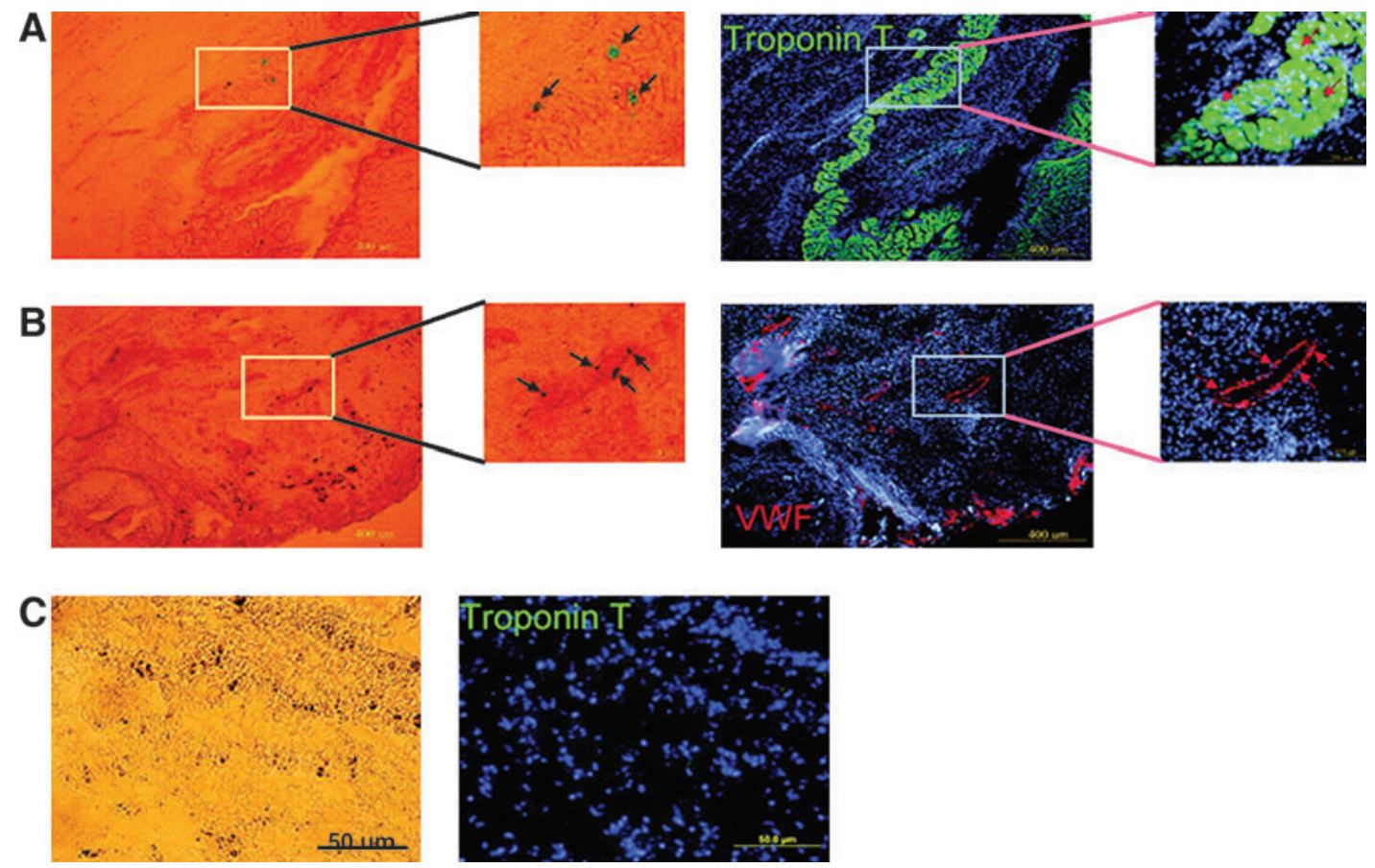

FIG. 1. Engraftment and differentiation of pMultistem in vivo. Infarcted swine hearts with $\beta$-galactosidase (LacZ)-labeled pMultistem injection were harvested and dissected into $10-\mu \mathrm{m}$ sections. Dissected samples were fixed in zinc fixative and stained for both LacZ (blue) and troponin T or VWF. Nuclei were stained by DAPI. (A) IZ of a Lac-Z+ pMultistem-treated heart expressing cardiac myocyte phenotype troponin T. The left two pictures are phase-contrast images with magnifications of $\times 10$ and $\times 40$, respectively. The right two pictures are fluorescence images with magnifications of $\times 10$ and $\times 40$, respectively. Patches of spared myocytes were observed only in the pMultistem-treated hearts, not in untreated hearts (shown in B). (C) Lac-Z+ pMultistem cells in vascular structures that coexpress VWF. The arrows indicate LacZ-positive cells stained with troponin T and VWF markers (reprinted with permission from Zeng et al.) (157). DAPI, 4',6-diamidino-2-phenylindole; IZ, infarct zone; VWF, von Willebrand factor.

cardiomyocytes in the infarct zone (Fig. 2). Moreover, the border zone (BZ) protein expression of creatine kinase-mt and creatine kinase-m isoforms was significantly reduced in infarcted hearts but recovered significantly in response to cell transplantation (Fig. 3). Our laboratory recently employed a transcoronary catheter delivery system to directly inject BMderived MPCs into the myocardium after myocardial infarction (146). This resulted in significant improvement in the ejection fraction and myocardial energetic. Histologic data demonstrated a $0.55 \%$ cell engraftment rate 4 weeks after MPC transplantation. Only 2\% of engrafted cells were costaining positive for cardiogenic markers (Fig. 4). Vascular density in the BZ was increased in the cell group (Fig. 5). Conditioned medium from cultured MPCs contained high levels of vascular endothelial growth factor, which was increased in response to hypoxia. We further demonstrated that MPCs cocultured with cardiomyocytes inhibited changes in cardiomyocyte mitochondrial membrane potential and cytochrome $c$ release induced by tumor necrosis factor- $\alpha$, thus suggesting that inhibition of apoptosis might be one of the paracrine effects of cell transplantation (Fig. 6) (146). We have also shown that there is no long-term engraftment of stem cells 4 months after transplantation (45). MPC transplantation results in long-term improvement in LV chamber function with a decreased infarct size, which is accompanied by improvement of myocardial energetic. It is associated with differential expression of genes relating to metabolism and apoptosis, including a downregulation of mitochondrial oxidative enzymes and upregulation of MEF2a and ZFP91 (45).

\section{Endothelial progenitor cells}

EPCs were first isolated from blood in 1997 (9). They originate from a common hemangioblast precursor in the BM (80). However, many other cells, including myeloid/monocyte (CD14+) cells and stem cells from adult organs, can also differentiate into cells with EPC characteristics. Thus, circulating EPCs are a heterogeneous group of cells originating from multiple precursors within the BM and present in different stages of endothelial differentiation in peripheral blood. Therefore, the characterization of these cells is difficult because they share certain surface markers of hematopoietic cells and some adult endothelial cells. Typically, they express CD34 (a hematopoeitic cell characteristic), CD-133 (a more specific marker of EPCs), and kinase insert domain-containing receptor, which is the receptor for vascular endothelial growth factor. In a study of sex-mismatched BM transplant patients by Hebbel and coworkers, 95\% of circulating endothelial cells in the peripheral blood of the transplant patients had recipient genotype, but $5 \%$ had donor genotype (70). The endothelial cells with donor phenotype had delayed growth in culture but had high proliferative capacity with 1023fold expansion within 1 month and were termed endothelial outgrowth cells. They concluded that the endothelial out- 


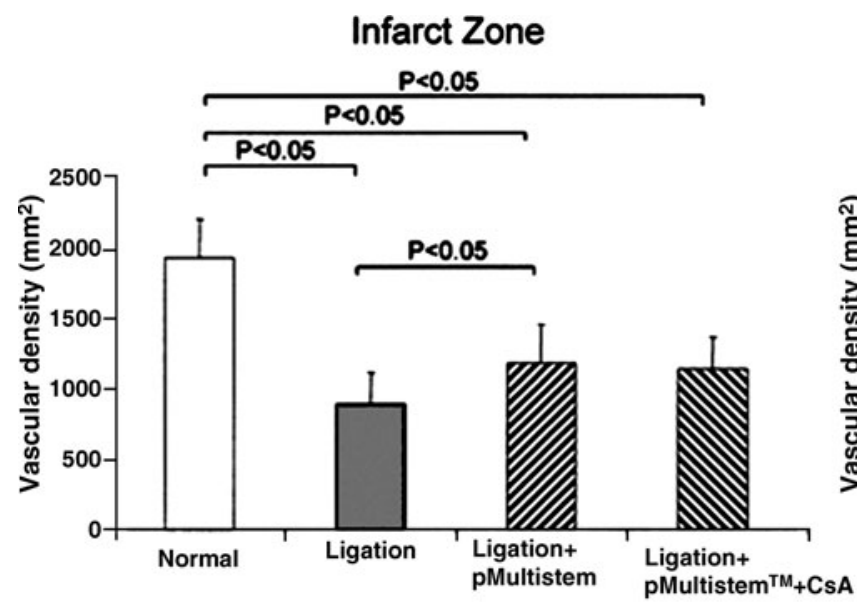

\title{
Border Zone
}
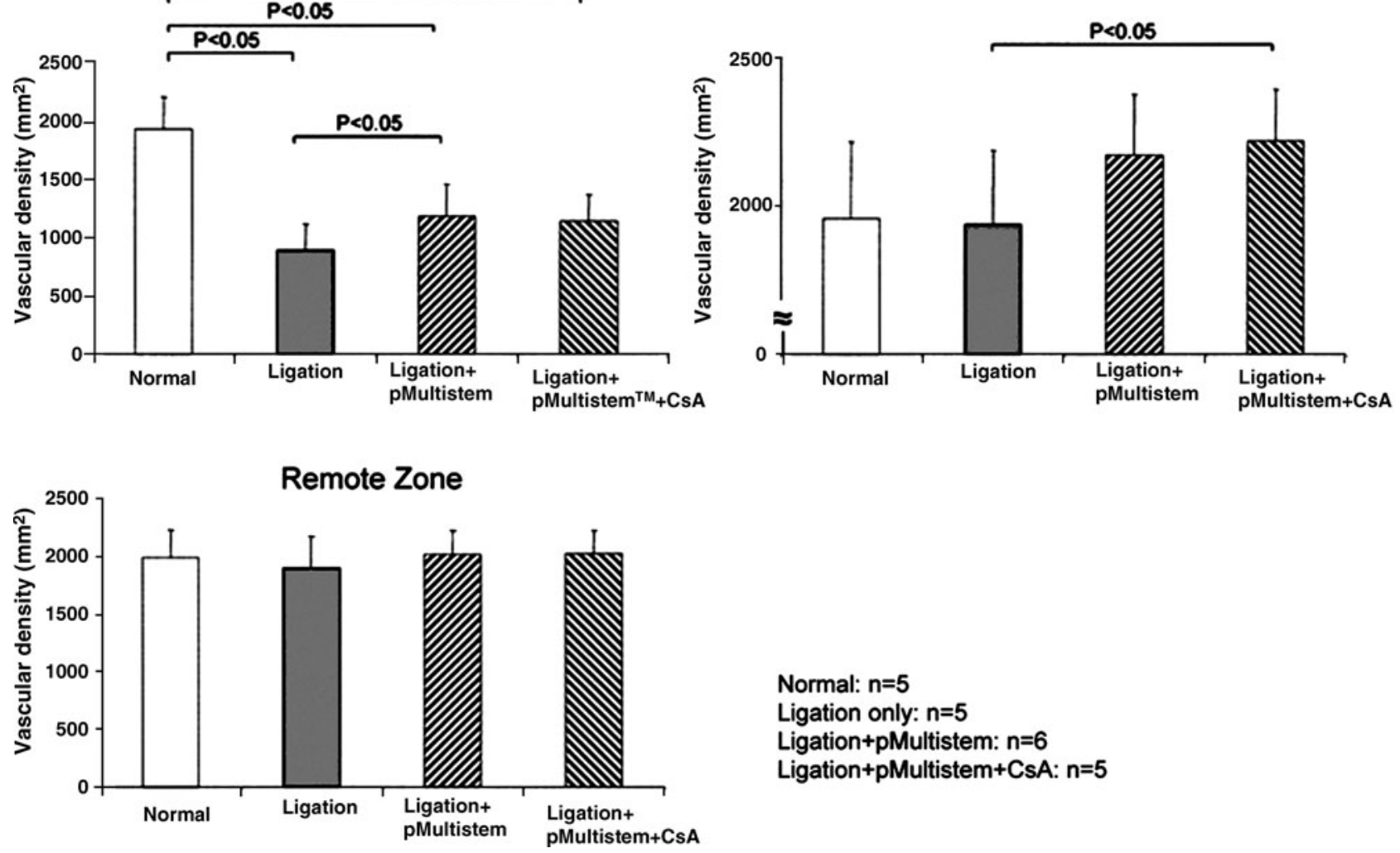

\author{
Normal: $n=5$ \\ Ligation only: $n=5$ \\ Ligation+pMultistem: $n=6$ \\ Ligation+pMultistem+CsA: $n=5$
}

FIG. 2. Cardiac sections from IZ, BZ, and remote-zone myocardium stained with von Willebrand factor and CD31. Vascular density was significantly higher in both the IZ and BZ of the pMultistem-treated hearts (reprinted with permission from Zeng et al.) (157). BZ, border zone.

growth cells were of $\mathrm{BM}$ origin. In contrast, the cells with recipient phenotype only had a 17 -fold expansion within the same time period. These circulating endothelial cells most probably originated from the vessel wall.

EPCs have been used in different animal models of cardiovascular disease. Intravenous delivery of CD34+ cells into athymic nude rats with myocardial infarction caused angiogenesis in the peri-infarct region, leading to decreased myocyte apoptosis, reduced interstitial fibrosis, and improvement of left ventricular function (56). Similarly, intramyocardial implantation of CD34+ selected human peripheral blood mononuclear cells into nude rats after myocardial infarction resulted in neovascularization and improved left ventricular function (51).

\section{UCB stem cells}

Human UCB is rich in stem and progenitor cells, which have high proliferative capacity $(69,83,91)$. Human UCB contains fibroblast like cells termed unrestricted somatic stem cells, which adhere to culture dishes, are negative for c-kit, CD34, and CD45 and differentiate in vitro and in vivo into variety of tissue types, including cardiomyocytes (57). Direct intramyocardial injection of these human unrestricted somatic cells into the infarcted hearts of immunosupressed pigs resulted in improved perfusion and wall motion, reduced infarct size, and enhanced cardiac function (54). Further, intravenous injection of human mononuclear UCB cells, a small fraction of which were CD34+, into NOD/scid mice lead to enhanced neovascularization with capillary endothelial cells of both human and mouse origin and reduced infarct size (74). However, no myocytes of human origin were found arguing against cardiomyogenic differentiation and regeneration of cardiomyocytes from donor cells. Additionally, direct intramyocardial injection of UCB CD34+ cells into the peri-infarct rim in a rat model resulted in improved cardiac function (38).

\section{Cardiac stem cells}

Can the heart regenerate? The ability of the cardiomyocytes to replicate has been a highly controversial topic. It is known that increases in cardiac mass in mammals during fetal life occur mainly due to cardiomyocyte proliferation. However, during the perinatal period, mammalian cardiomyocytes are known to withdraw from the cell cycle, thus limiting their ability to divide and increase in number $(75,116$, 127). Thus, normal postnatal growth and adaptive increases in cardiac mass in adults as a result of hemodynamic burden are achieved mainly through increase in cell size known as hypertrophy $(75,116,127)$. This belief was supported by the inability to identify mitotic figures in myocytes, as well as the observation that regions of transmural infarction evolved into essentially avascular, thin collagenous scar. This paradigm has been dominant over the past 50 years and views the heart as a postmitotic organ consisting of a predetermined number of parenchymal cells that is defined at birth and preserved 

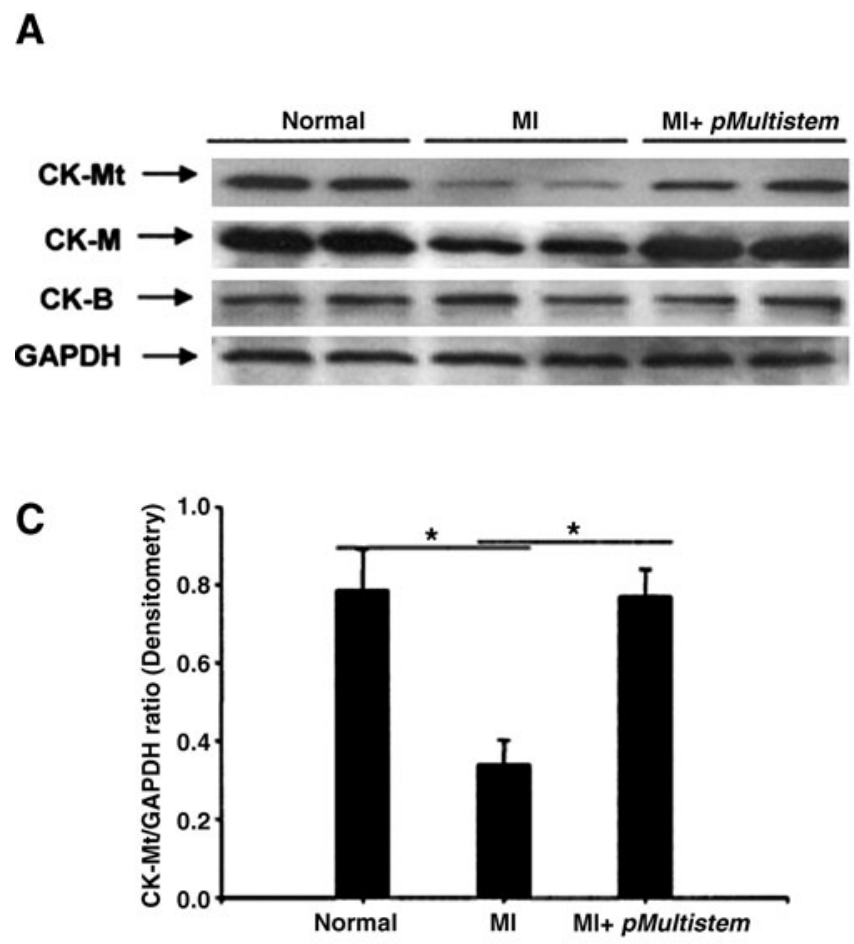
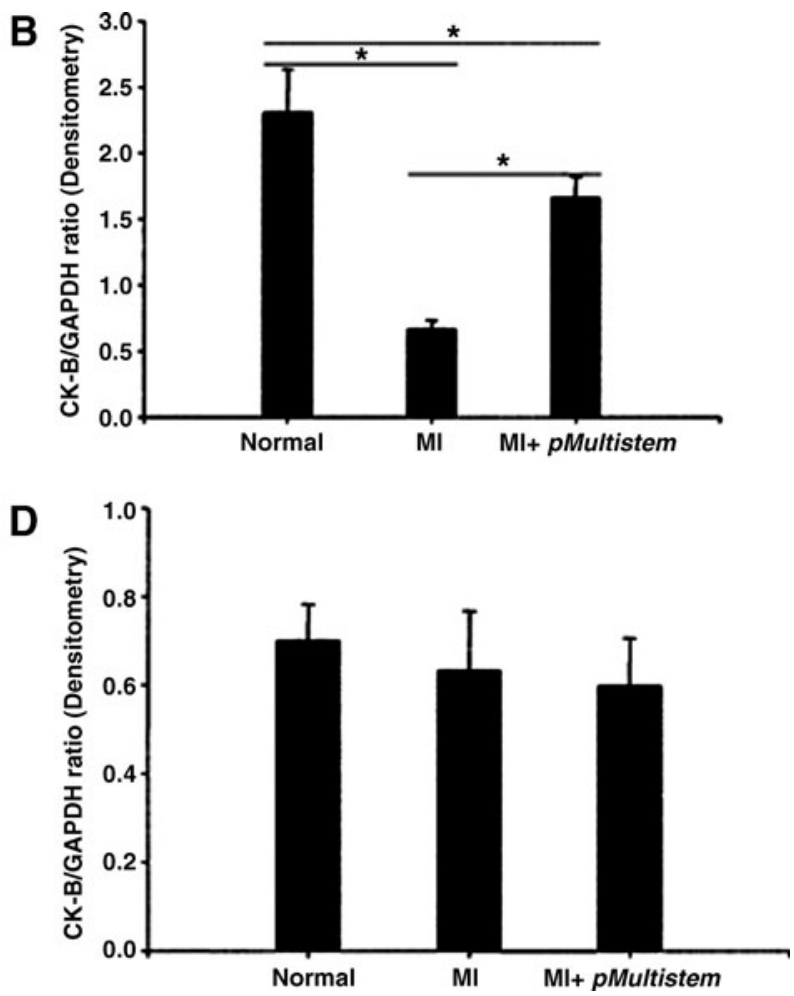

FIG. 3. Representative Western blots from normal hearts [Normal], hearts with postinfarction left ventricle (LV) remodeling [MI], and a heart with myocardial infarction (MI) that received cell transplantation [MI+pMultistem] showing protein levels of myocardial CK isoforms (A) and the respective normalized data (to GAPDH) in B, C, and D. Values are mean \pm SD. ${ }^{*} p<0.05$. The same blots reprobed with GAPDH antibody were used as controls for equal loading (reprinted with permission from Zeng et al.) (157).

throughout life until the death of the organ and organism. However, recent studies over the past few years have challenged this concept of the heart being an organ incapable of regeneration. The human heart contains cycling myocytes undergoing mitosis under normal and pathological conditions $(5,16,93,112)$. In a swine model of chronic hibernating myocardium, it was shown that pravastatin increased myocytes in mitosis (increased myocyte nuclear phospho-histoneH3 positivity) and the growth phase of cardiac cycle (increased myocyte nuclei expressing Ki67), which caused an increase in myocyte proliferation as reflected by an increase in myocyte nuclear density coupled with a reduction in myocyte size (131).

Although myocyte regeneration from endogenous cardiac progenitors is sparse, there are a few reports demonstrating this pathway. The young feline heart has a population of small mononucleated ventricular myocytes that incorporate Bromodeoxyuridine, express markers of cell cycle activity (Ki67), and have telomerase activity (21). Recently, Dr. Bolli and associates demonstrated that coronary infusion of c-kit+ cardiac progenitor cells (CPCs) in a rat model of chronic myocardial infarction was associated with functional improvement. They further showed that this was related to stimulation of endogenous CPCs (135)

Recently, Bergmann et al. utilized radiocarbon cellular dating to examine cardiomyocyte turnover (17). ${ }^{14} \mathrm{C}$ concentration in the atmosphere increased sharply during the cold war because of the above ground nuclear tests that persisted until the 1963 Limited Nuclear Test Ban Treaty. The author's ingenious method is based on the fact that ${ }^{14} \mathrm{C}$ concentration in the human body mirrors that in the atmosphere at any time and the concentration of ${ }^{14} \mathrm{C}$ in the DNA is a reflection of when the cell was born. Using this technique, they showed that the adult heart is capable of cellular turnover at the rate of $1 \%$ per year and $45 \%$ of the cardiomyocytes have been generated by the age of 50 years (17). Another study used genetic fate mapping to demonstrate that progenitor cells contribute to the replacement of cardiomyocytes after injury (41). They generated double transgenic mice and labeled the cardiomyocytes with GFP after a pulse of tamoxifen. There was little or no cardiomyocyte turnover during normal aging, but the percentage of GFP+ cardiomyocytes decreased from $82.8 \%$ in heart tissue from sham-treated mice to $67.5 \%$ in areas bordering a myocardial infarction, $76.6 \%$ in areas away from a myocardial infarction, and $75.7 \%$ in hearts subjected to pressure overload, indicating that stem cells or precursor cells had refreshed the cardiomyocytes (41). Recently, Anversa and colleagues examined the percentage of myocytes, endothelial cells, and fibroblasts labeled by iododeoxyuridine in postmortem samples obtained from cancer patients who received the thymidine analog for therapeutic purposes (47). They observed a higher percentage of cell turnover with an average $22 \%, 20 \%$, and $13 \%$ new myocytes, fibroblasts, and endothelial cells generated per year, suggesting that the lifespan of these cells was $\sim 4.5,5$, and 8 years, respectively (47). Importantly, DNA repair, ploidy formation, and cell fusion were not implicated in the assessment of myocyte regeneration. 
A Infarct

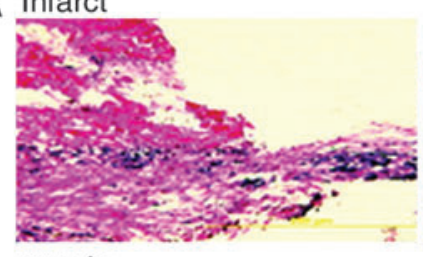

remote

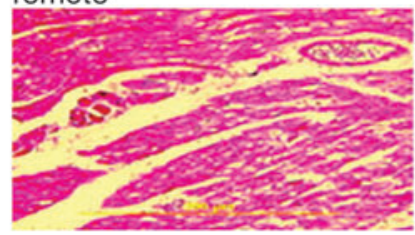

B
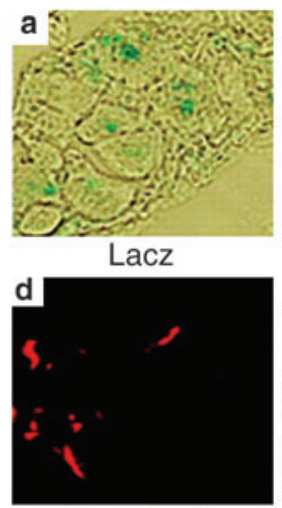

$\mathrm{N}$-cadherin

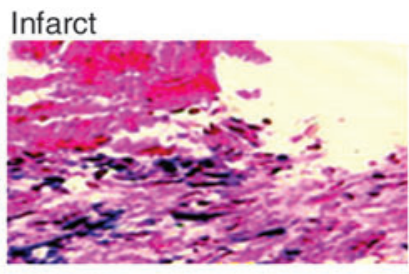

remote
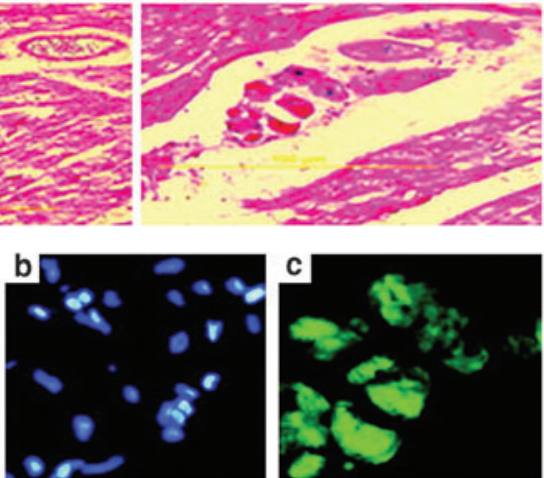

DAPI

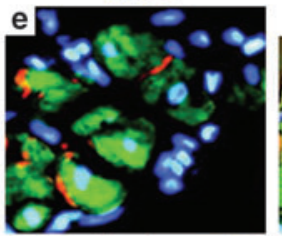

$\mathrm{N}$-cadherin CTNT

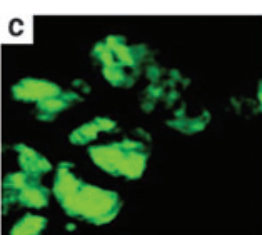
CTNT

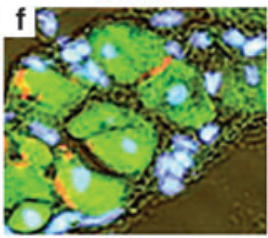

Merge
C
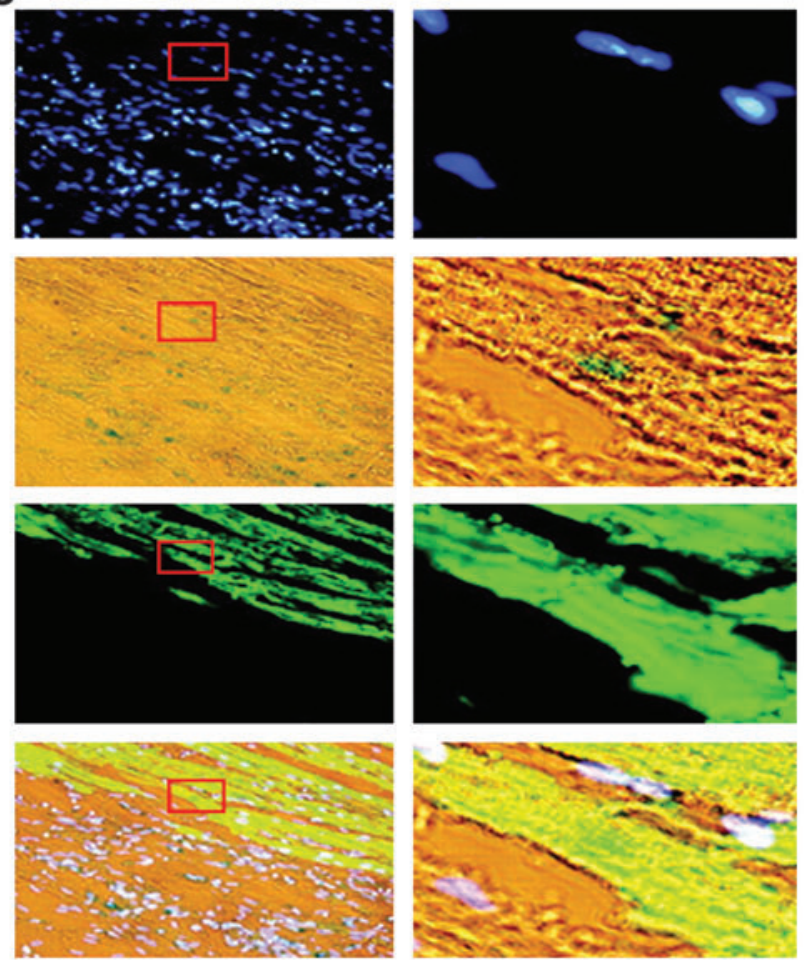

FIG. 4. Histologic staining of tissues from the heart 10 days after transplantation of retrovirus LacZ-labeled swine MPCs. (A) Hematoxylin-eosin staining of tissues from the heart 10 days after transplantation of retrovirus LacZ-labeled swine MPCs. Left panel shows that the engrafted cells (LacZ) are distributed in peri-infarct and remote regions (magnification $\times 100$ ); right panel shows the same sections at high magnification (magnification $\times 400)$. (B) Engraftment and differentiation of swine MPCs in vivo. Swine MPCs labeled with LacZ were injected into MI hearts via transmural catheter delivery, and the tissues were harvested and dissected into 10- $\mu \mathrm{m}$ sections. Dissected samples were stained for LacZ (dark blue), troponin T (green), and/or N-cadherin (red). Nuclei were stained with DAPI (blue). Upper panel (a-c), low magnification; lower panel (df), high magnification. (C) Engraftment and differentiation of swine MPCs in vivo. Dissected samples were stained for LacZ (blue) and $\alpha$-sarcomeric actin (green). Nuclei were stained with DAPI (blue). Left panel, low magnification; right panel, high magnification (reprinted with permission from Wang et al.) (146). cTNT, cardiac troponin-T; MPC, multipotent progenitor cell.

The heart may belong to the group of constantly renewing tissues in which the capacity to replace cells depends on the persistence of a stem cell compartment $(7,130)$. The resident $\mathrm{CPC}$ is responsible for the constant turnover of cardiomyocytes, endothelial cells, smooth muscle cells, and fibroblasts. This raises the question of why the ischemic myocardial damage not spontaneously repaired and heart failure cannot be avoided or ultimately cured. It has been postulated that the progressive nature of ischemic cardiomyopathy may partly be due to an inability of progenitor cells to home to an infarcted region. The CPCs in the infarcted region die by apoptosis and necrosis in an identical manner to the other cardiomyocytes in that region. Thus, in most cases tissue growth does not invade the region of infarct but occurs in viable myocardium only (16, 143). The notion of an aging myopathy in humans has also been put forward that is characterized by cellular senescence, growth limitation, and enhanced death of CPCs and myocytes (22). Thus, a defective CPC compartment may be a common denominator of heart failure of different etiology whether the initiating event is ischemic myocardial injury, aging, or diabetes (48).
Isolation of CPCs. CPCs have been isolated using five different approaches. Beltrami et al. (15) isolated cells expressing the receptor for stem cell factor (c-kit) from the interstitial regions of adult myocardium of rats. The highest densities of these lineage negative c-kit + stem cells were in the atria and ventricular apex. These cells were self-renewing, clonogenic, and multipotent. Further, they had the ability to differentiate into cardiomocytes, endothelial cells, and smooth muscle cells. Recently, the same group has demonstrated that the human heart also possesses these c-kit + cells that can acquire the myocyte, smooth muscle cell, and endothelial cell lineages in vitro and in vivo (14). Resident murine CPCs have also been separated on the basis of presence of Sca-1 (99). A small percentage of these cells activated cardiac genes but did not beat in response to DNA demethylation with 5-azacytidine (99). However, this group showed with the help of Cre (type 1 topoisomerase from P1 bacteriophage) recombinase techniques that the apparent cardiac differentiation was the result of cell fusion in $50 \%$ of cases (99). Matsura et al. also isolated Sca- $1+$ cells from adult murine hearts, which differentiated into beating cardiomyocytes in the presence of oxytocin but not 5-azacytidine 
A

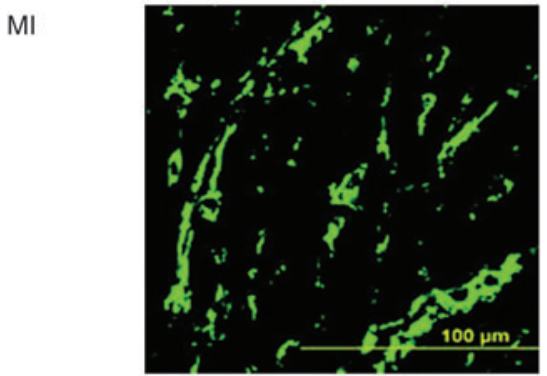

$\mathrm{Ml}+\mathrm{MPCs}$

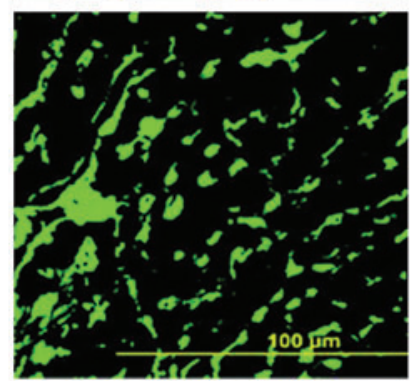

B

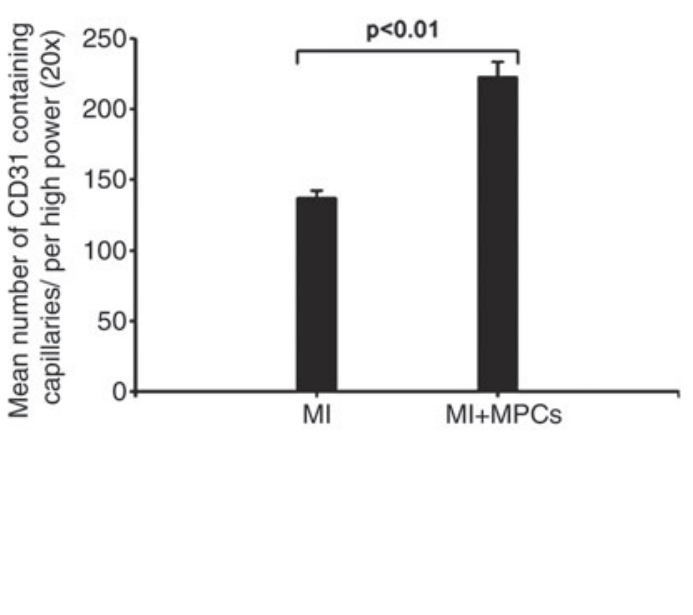

FIG. 5. Transplantation of MPCs into MI hearts significantly promoted angiogenesis, which was probably mediated by release of VEGF. (A) Immunofluorescence staining of tissues from MI and MPC transplantation heart. (B) Mean number of CD31containing capillaries in the BZ myocardium $(n=6$, $p<0.01)$. Data are mean \pm SD (reprinted with permission from Wang et al.) (146).
(81). Other groups have isolated so called SP cells from mouse hearts based on their ability to exclude Hoechst 33342 dye (78, 107). These cells express Abcg2, an ATP-binding cassette transporter. They are Sca-1+ and c-kit low and differentiate into cardiomyocytes after coculture with rat cardiomyocytes. Laugwitz et al. discovered a group of cells from postnatal mouse hearts using isl-1 (homeobox gene islet-1) transcription factor (64). These also express the cardiac transcription factors Nkx2.5 and GATA4 but not Sca-1, c-kit or CD31. These cells also have the ability to differentiate into functional cardiomyocytes in vitro and in vivo. The isl-1+ cells have not been identified in adult hearts (64). Messina et al. isolated undifferentiated cells that grow as self-adherent clusters (termed "cardiospheres") from subcultures of postnatal atrial or ventricular human biopsy specimens and from murine hearts (85). These cells had the properties of adult CSCs as they were clonogenic, expressed stem and EPC antigens/markers, were capable of long-term self-renewal, and could differentiate in vitro and in vivo into myocytes and endothelial cells (85). Later, Marban's group obtained tissue from percutaneous endomyocardial biopsies in humans and pigs, and grew it in primary culture to form cardiospheres, which were further plated to yield cardiosphere-derived cells (CDCs) (126). Cardiospheres and CDCs expressed antigenic characteristics of stem cells at each stage of processing, as well as proteins vital for cardiac contractile and electrical function (126). Human and porcine CDCs cocultured with neonatal rat ventricular myocytes exhibited biophysical signatures characteristic of myocytes, including calcium transients synchronous with those of neighboring myocytes (126).

Number of CPCs. Anversa and coworkers claim that CPCs are undifferentiated cells that express the stem cellrelated antigens, c-kit, multiple drug resistance 1 (MDR-1; another ATP-binding cassette transporter), and Sca-1, in variable combinations (68). Quantitative data in the mouse, rat, dog, and human heart have demonstrated that there is 1 CPC per 30,000-40,000 myocardial cells. Approximately $65 \%$ of all CPCs possess the three stem cell antigens (Scas), $\sim 20 \%$ two Scas and $\sim 15 \%$ only one. Approximately $5 \%$ each of these CPCs exclusively express c-kit, MDR-1, or Sca-1 (68).

Significantly, none of the above-mentioned reports demonstrate a signature CPC phenotype. This cell population also has significant overlap in expression of other surface markers. It remains to be elucidated whether these cells are actually the same stem cell type and that differing surface markers reflect differing developmental phases or qualitatively separate subpopulations. These CPCs may participate in myocyte turnover, the rate of which remains to be determined.

Origin of the CPC. The origins of CPCs also remain unclear. The cycling cardiomyocytes might be derived from uncommitted stem-like population cells that reside in the heart and expand and differentiate into cardiomyocytes in response to proper stimulation. Alternatively, these stem-like cells may reside in the $\mathrm{BM}$ and then be mobilized into the circulation and induced to home to the heart by signals emanating from the injured heart.

Mouquet et al. demonstrated that cardiac SP cells are maintained by local progenitor cell proliferation under physiological conditions (90). After myocardial infarction, this cardiac SP is decreased by as much as $60 \%$ in the infarct and to a lesser degree in the noninfarct regions within 1 day. Cardiac SP pools are subsequently reconstituted to baseline levels within 7 days after myocardial infarction, through both proliferation of resident cardiac SP cells and by homing of BM-derived stem cells to specific areas of myocardial injury. These cells then undergo immunophenotypic conversion and adopt a cardiac SP phenotype (CD45+ to CD45-) (90). BMderived stem cells accounted for $\sim 25 \%$ of the SP cells in the heart under pathological conditions as compared to $<1 \%$ under physiological conditions (90). In addition to these CD45+ cells that Mouquet et al. reported, BM also contains CD45-, CXCR4+, and Sca-1+ cells within the nonadherent, nonhematopoietic mononuclear fraction which express early cardiac markers such as Nkx2.5 and GATA-4 (60). These cells mobilize into blood after myocardial infarction and home to the infarcted myocardium in mice. Cerisoli et al. (20) also 


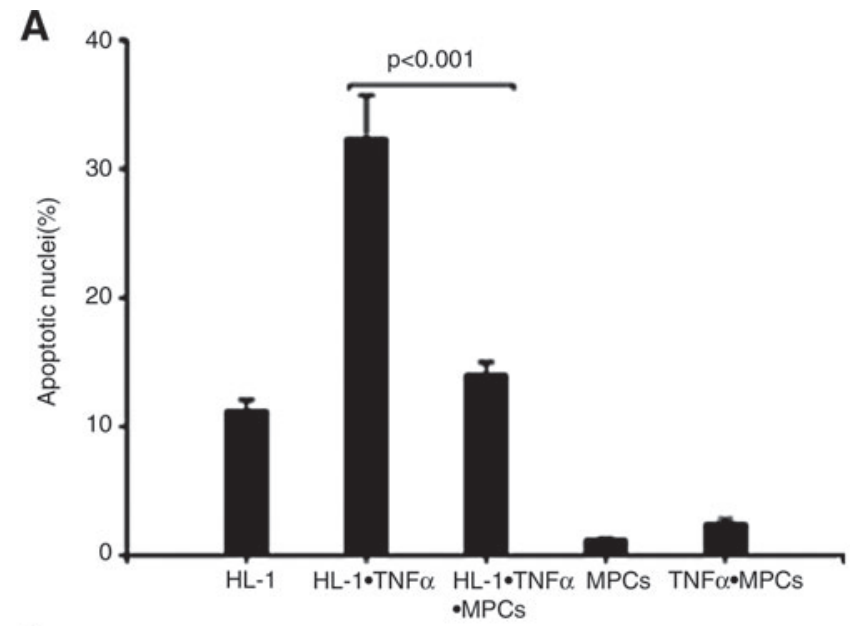

B

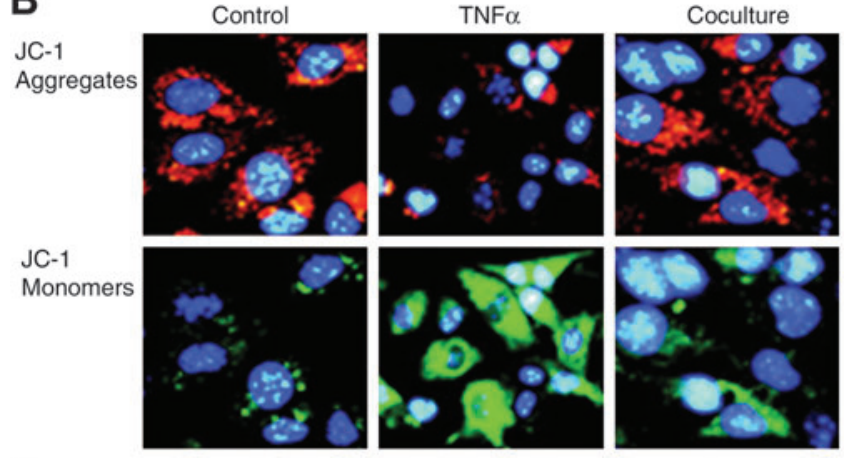

C

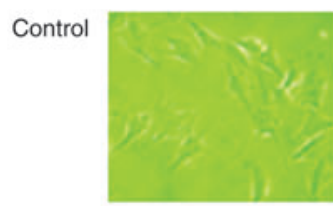

Swine MPCs

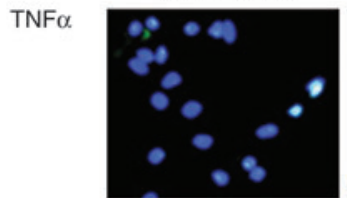

DAPI,CytoC

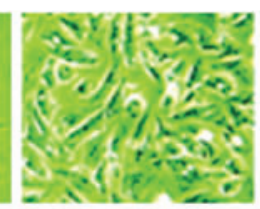

Cardiomyocyte MPCs.Cardiomyocyte

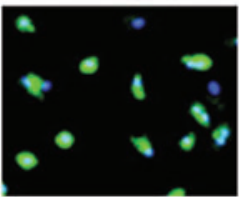

DAPI,CytoC

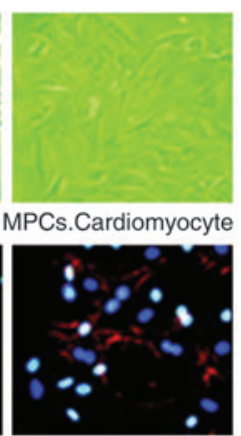

DAPI,CytoC.CTnT

FIG. 6. The protective effect of MPCs on cardiomyocytes. (A) Cocultured swine MPCs and HL-1 cells significantly inhibited TNF- $\alpha$-induced HL- 1 cell apoptosis $(n=6, p<0.001)$. Data are mean \pm SD. (B) Swine MPCs cocultured with HL-1 cells significantly inhibited TNF- $\alpha$-induced mitochondrial membrane potential changes. (C) Swine MPCs cocultured with rat neonatal cardiomyocytes significantly inhibited TNF- $\alpha$-induced cytochrome $c$ release (reprinted with permission from Wang et al.) (146).

showed that (at least in pathological conditions) part of the c-kit + CPC population may derive from cells that originate in the $\mathrm{BM}$ and are able to adopt in the heart the same functions and features of the local CPC.

Myocardial regeneration from CPCs. Anversa and coworkers showed that the direct intramyocardial injection of c-kit+ cells into an ischemic rat heart reconstituted welldifferentiated myocardium, comprised of blood-carrying

new vessels and cardiomyocytes with the characteristics of young cells; these cells were present in $\sim 70 \%$ of the ventricle (15). Later, it was also shown that intracoronary delivery of these CSCs in an ischemia/reperfusion rat model resulted in myocardial regeneration, infarct size reduction of $29 \%$, and improvement of left ventricular function (25). Given intravenously after ischemia/reperfusion, Sca-1 cells also homed to injured myocardium and differentiated into cardiomyocytes (99). The relative contributions of regenerated cardiomyocytes and preservation of injured native cardiomyocytes in these studies requires clarification.

Our laboratory recently reported that heart-derived Sca$1+/$ CD31- cells possess stem cell characteristics and play an important role in cardiac repair (145). In that study, immunofluorescent staining and fluorescence-activated cell sorter (FACS) analysis indicated that endogenous Sca-1+/CD31cells significantly increased in the infarct and peri-infarct areas at 3 and 7 days after MI. Western blotting confirmed elevated Sca-1 protein expression 7 days after MI. Sca-1+/ CD31- cells cultured in vitro were induced to express both endothelial cell and cardiomyocyte markers. Transplantation of Sca-1+/CD31 - cells into a murine model of MI led to functional preservation and decreased remodeling after MI (145). Immunohistochemistry data indicated a significant increase of neovascularization, but a low level of cardiomyocyte regeneration at the infarct BZ. Despite the absence of significant cardiomyocyte regeneration, cell transplantation remarkably improved myocardial bioenergetics (145). These findings provide evidence that Sca-1+/CD31- cells possess both endothelial cell and cardiomyocyte progenitor cell characteristics. However, this study also reported that the regeneration rates of cardiomyocytes or endothelial cells from the engrafted stem cells were very low (only $\sim 80$ cells per heart). Hence, trophic effects associated with the transplanted cells were most likely the basis of the beneficial effects of these cells (145). Expansion of these progenitor cells may have therapeutic applicability to the treatment of myocardial infarction

CPCs and early committed cells express c-Met and insulinlike growth factor (IGF) I receptors and synthesize and secrete the corresponding ligands, HGF and IGF-1 (142). HGF mobilizes CSCs early committed cells and IGF-1 promotes their survival and proliferation (142). Therefore, in another study, HGF and IGF-1 were injected in mice with myocardial infarction and a growth factor gradient was introduced between the site of storage of primitive cells in the atria and the region bordering the infarct to facilitate homing. The newly formed myocardium contained arterioles, capillaries, and functionally competent myocytes that increased in size over time. This regeneration as associated with improved ventricular performance and induced increased survival. Surprisingly, this intervention rescued animals with infarcts that comprised $86 \%$ of ventricular mass. The above findings have been replicated in a dog model, where HGF and IGF-1 were also used to stimulate resident CSCs after myocardial infarction, and growth factor therapy again resulted in improvement of myocardial function (71).

Before their therapeutic use, CPCs have to be isolated from fragments of myocardium and expanded in vitro. This was achieved in a pig model (13), where c-kit+ cells were isolated and each cell was propagated to form $\sim 400,000$ cells. Another group performed autologous transplantation of CPC in an 
ischemia/reperfusion swine model (46). Each pig had a biopsy from the right ventricular septum at the time of injury. The biopsies weighed $92 \mathrm{mg}$, and yielded a mean cell counts of $14.2 \times 10^{6}$ cells after isolation and expansion (after 2.8 cell passages over 23 days). Intracoronary delivery was performed 4 weeks after injury. Engraftment occurred in the MI $\mathrm{BZ}$ and islands of engrafted cells were present within the scar 8 weeks after coronary delivery (46).

Human CPCs have also been isolated from myocardium, expanded in vitro and then used for transplantation in animal models of ischemic myocardium. Hosoda et al. isolated human CPCs (hCPCs) from surgical samples (40). These c-kit+ hCPCs were injected into the hearts of immunodeficient mice and rats. Foci of myocardial regeneration were identified at 2 3 weeks and consisted of myocytes, resistance arterioles, and capillaries (40). The presence of connexin 43 and N-cadherin in the developing human myocytes strongly suggested that the engrafted human cells were becoming functionally competent. Two-photon microscopy was used to further demonstrate the functional integration of enhanced GFP+ human myocytes with the surrounding myocardium (40). Torella et al. (140) has also isolated hCPCs from myocardial samples from all four chambers of the human heart. These were c-kit+, MDR-1+ and CD133+. One clone could generate over $5 \times 10^{9}$ cells and form functional myocardium after injection into infarcted rat hearts (140).

These studies provide a rationale for the use of hCPCs in patients with ischemic heart disease. These cells seem to be excellent candidates for exogenous stem cell therapy, but they have to be harvested from patients and expanded ex vivo to generate numbers sufficient for transplantation.

\section{Embryonic stem cells}

ESCs have tremendous therapeutic potential because they are totipotent. They have the capacity to divide in an undifferentiated state while maintaining their ability to differentiate into cells belonging to all three embryonic germ layers. However, transplantation of these cells has certain limitations: they can form teratomas (137) and are immunogenic (98), and there are ethical concerns regarding their use.

Mouse ESCs. The cardiogenic potential of mouse ESCs (mESCs) was first demonstrated in 1985 when these cells were cultured in suspension and formed 3-dimensional cystic bodies, termed embryoid bodies (EBs), which differentiated into cell types of the visceral yolk sac, blood islands, and myocardium (27). Nowadays, cells undergo a step of feeder layer subtraction and then are resuspended in leukemia inhibitory factor-free culture medium at a very low density (150). mESCs are cultured in small drops that are formed on the lid of tissue culture dishes. When kept in this hanging droplet setting for 2 days, the cells aggregate and form differentiating EBs (150). EBs are then transferred into ultralow attachment dishes where they further differentiate. Spontaneous contracting cells (cardiomyocytes) can be observed between 7 and 8 days of differentiation (150). This process of cardiac differentiation can be enhanced by growth factors. Treatment of mESCs with tranforming growth factor (TGF)$\beta 2$, but not TGF- $\beta 1$ or $-\beta 3$ isoform, significantly increased EB proliferation as well as the extent of the EB outgrowth that beat rhythmically (125). These authors demonstrated that $49 \%$ of the EBs treated with TGF- $\beta 2$ exhibited spontaneous beating compared with $15 \%$ in controls at 17 days (125). Exposure to bone morphogenetic protein 2 (BMP2) and fibroblast growth factor 2 has also been shown to enhance the differentiation of ES cells into beating cardiac myocytes (50).

mESCs and mESC-derived cells have been shown to engraft and regenerate myocardium after $\mathrm{MI}(59,86,121)$. These cells can form cardiomyocytes that couple electrically with the host myocardium, endothelial cells, and blood vessels $(59,86$, 121). Transplantation of mESCs in infarcted hearts significantly reduced apoptosis, fibrosis, and hypertrophy at 2 weeks (122). This was thought to be a paracrine effect as conditioned medium from mESCs inhibited $\mathrm{H}(2) \mathrm{O}(2)$ induced apoptosis of cardiac myoblast H9c2 cells (123). These antiapoptotic effects were significantly inhibited with tissue inhibitors of metalloproteinase- 1 antibody, suggesting that tissue inhibitors of metalloproteinase- 1 is an important factor to inhibit apoptosis (123). This decrease in apoptosis is associated with an increase in phosphorylated Akt, and the increased activity was attenuated with an Akt inhibitor, suggesting that the Akt pathway is involved in the decreased apoptosis and cell survival provided by ES-cardiomyocyte (CM) (124).

More recently, three different CPCs derived from mESCs have been characterized $(49,89,151)$; Brachyury $+/$ Flk + and homeobox gene islet-1 (Isl1+) CPCs were shown to differentiate into cardiomyocytes, endothelial cells, and smooth muscle cells, whereas Nkx2-5/Kit CPC could differentiate into cardiomyocytes and smooth muscle cells.

Human ESCs. Human ESCs (hESCs) were first isolated from the human blastocyst in 1998 (137), and later it was shown that they could differentiate into cardiomyocytes (52). Reverse transcription-polymerase chain reaction (RTPCR) and immunohistochemical studies demonstrate that hESC-CMs express early cardiac-specific transcription factors, sarcomeric proteins, and gap junction proteins (152). Electrophysiologic studies showed that most of the hESCderived cardiomyocytes resemble human fetal ventricular myocytes that can propagate action potentials (53). They have intact $\beta$ adrenergic signaling as demonstrated by a dose-dependent inotropic and chronotropic response to isoproterenol. hESCs can also differentiate into endothelial and smooth muscle cells (118).

Several methods have been used to derive cardiomyocytes from hESCs. As is the case with mESCs, the most common method for deriving cardiomyocytes from hESCs is through the formation of spontaneously contracting three dimensional aggregates known as EBs (52). Unfortunately, the purity of cardiomyocytes is very poor with this technique, yielding $<1 \%$ cardiomyocytes as a percentage of total hEB-derived cells $(52,62)$. A different approach utilized by the Mummery group was based on the concept that the anterior endoderm plays a critical role in the cardiac induction of mesodermal structures. Human ES2, a hESC cell line that does not form EBs, was cocultured with END-2 cells, a visceral endoderm like derivative of undifferentiated murine p19 embryonal carcinoma cells $(32,105)$. A subset differentiated into cardiomyocytes based on immunocytochemical, electrophysiological, and calcium imaging studies. The efficiency of cardiogenesis was further enhanced by removal of serum from the coculture medium and/or addition of an inhibitor of 
p38 mitogen activated protein kinase. This resulted in an $\sim 20 \%-25 \%$ yield of cardiomyocytes $(32,105)$. Laflamme et al. developed a new technique to direct the differentiation of hESC into cardiomyocytes by sequential treatment of highdensity undifferentiated monolayer cultures with activin A and BMP4 (62). This protocol yielded $>30 \%$ cardiomyocytes. The Keller group induced a primitive streak like population and mesoderm with activin A, BMP4, and basic fibroblast growth factor followed by cardiac specification with the Wnt inhibitor, dickkopt homolog 1 (155). This generates a population of $40 \%-50 \%$ cardiomyocytes. This was further enhanced by sorting for an early cardiovascular progenitor based on expression of the Flk-1 tyrosine receptor kinase (155). None of the above protocols yield a homogenous preparation of cardiomyocytes, and thus further strategies are employed to purify these cells. Percoll gradient centrifugation, which allows specific enrichment of hESC-derived cardiomyocytes, can lead to cultures of $82.6 \% \pm 6.6 \%$ cardiomyocytes (62). The highest levels of cardiac purity are reached by genetic selection based on activation of either the human $\alpha-\mathrm{MHC}$ or MLC2v promoters, which can result in greater than $90 \%$ hESC cardiomyocytes $(4,42)$. Recently, Fukuda and colleagues have demonstrated a method for obtaining $>99 \%$ pure cardiomyocytes from hESC and human induced pluripotent stem cells (hiPSCs) cells by selectively staining the mitochondria of cardiomyocytes by the fluorescent dye, tetramethylrhodamine methyl ester perchlorate, and subsequent fluorescent activated cell sorting (35).

Initial in vivo studies have demonstrated that hESC-derived cardiomyocytes can form new myocardium in the uninjured heart of athymic rats (63) or immunosuppressed pigs (53). The size of the graft can be increased fourfold by before heat-shock treatment of the cells (63). When hESCs are implanted in slow heart rate species such as pigs or guinea pigs, they can form pacemakers when the native one is dysfunctional, implying electrical integration with surrounding cardiomyocytes (53, 153). However, when these cells are transplanted in the setting of myocardial infarction, only $18 \%$ form myocardial grafts and these grafts also contain substantial noncardiac elements (62). However, this group used the guided differentiation methods along with the Percoll purification methods and combined it with a prosurvival cocktail to improve graft survival in infarcted hearts. This cocktail included Matrigel to prevent anikis, a cell-permeant peptide from B-cell lymphomaextra large (member of Bcl-2 family of proteins) to block mitochondrial death pathways, cyclosporine A to attenuate cyclophilin D-dependent mitochondrial pathways, a compound that opens ATPdependent $\mathrm{K}+$ channels (pinacidil) to mimic ischemic preconditioning, IGF-1 to activate Akt pathways, and the caspase inhibitor ZVAD-fmk (62). Transplantation of hESC-derived cardiomyocytes with this prosurvival cocktail in infarcted hearts caused consistent formation of myocardial grafts with improved ventricular function (62). The other interesting point of this study was that almost all noncardiac hESC-derived cells died by the 4 -week period (62).

\section{Induced pluripotent stem cells}

Development of mouse iPSCs and hiPSCs. The cloning of Dolly showed that somatic cells can be reprogrammed by transferring their nuclear contents into oocytes (149). This reprogramming can also be achieved by fusion with ES cells
$(23,132)$. These studies revealed that unfertilized eggs and ES cells contain factors that can confer totipotency or pluripotency to somatic cells and formed the basis of the seminal work performed by Takahashi and Yamanaka in 2006 (134).

They showed that pluripotent stem cells could be obtained by transducing mouse adult fibroblasts with a limited set of defined transcription factors (Oct3/4, Sox2, c-Myc, and Klf4) (134). These reprogrammed cells, named iPSCs, resembled ES cells in many of their characteristics. They exhibited the morphology and growth properties of ES cells and expressed ES cell marker genes (134). The pluripotency of the resultant murine iPSCs was rigorously confirmed using multiple techniques $(94,100,134,148)$. These cells showed in vitro differentiation into cell types of all three embryonic germinal layers. Subcutaneous transplantation of iPSCs into nude mice resulted in teratoma formation. Moreover, iPSCs contributed to mouse embryonic development after injection into blastocysts. Since this initial study, iPSC research has grown tremendously and to date iPSCs have been generated from cells from several species using different sets of reprogramming factors.

A number of groups subsequently reported the generation of human IPS Cells by reprogramming human somatic cells with overexpression of either Oct4, Sox2, c-Myc, and Klf4 or Oct4, Sox 2, Nanog, and LIN28 $(73,104,133,156)$. It is thought that the exogenous transcription factors only initiate the reprogramming since their later expression declines and the endogenous pluripotency network is upregulated. This eventually maintains the emerging iPSCs in an undifferentiated state. The human iPSC lines derived so far are similar to hESC in morphology, proliferation, gene expression, epigenetic status of pluripotency genes, and differentiation potential both in vitro and in vivo $(133,156)$.

Although still derived only at low efficiency $(\sim 0.01 \%)$, iPSCs have now been generated from a range of different somatic cells, including mouse liver and pancreatic cells (8, 128 ) and human keratinocytes from hair and cells from BM (1, 103). Depending on the expression levels of endogenous transcription factors, some cell types require fewer reprogramming factors. Adult mouse neuronal stem cells, for example, already express Sox and c-Myc and Klf4 and only need additional Oct3/4 to be reprogrammed (55). Although the viruses used to generate first generation iPSCs represent a potent tool to deliver genes into a target cell they have the disadvantage of random integration into the host genome. This can lead to alterations in the expression of endogenous genes or even cause cancer-inducing mutations. In addition, incomplete downregulation of transgenes during differentiation may lead to iPSC derivatives with an unstable or tumorigenic phenotype. Much current research is focused on reprogramming methods independent of integrating viral vectors that will be particularly important for any future therapeutic use. Transient expression of reprogramming factors with the help of nonintegrative adenovirus or plasmidmediated transfection $(101,129)$ have been described as well as the use of specific small molecules, which could replace two of the reprogramming factors (119). Recently, Zhou et al. demonstrated for the first time that somatic cells (i.e., murine fibroblasts) can be fully reprogrammed into pluripotent stem cells by direct delivery of recombinant reprogramming proteins (159). This protein transduction method is simpler and faster and eliminates any risk of modifying the target cell 
genome by exogenous genetic sequences. It has also been suggested that microRNAs (tiny RNA molecules that regulate gene expression by binding to other RNAs such as mRNA) play an important role in the switch between the pluripotent and differentiated states. mESCs express let-7 microRNAs at low levels that must be induced to trigger cell differentiation, and seems to be essential for reducing the concentrations of the stemness factors (84). Differentiated cells, however, express low levels of the stemness factors and high levels of let-7. Inhibition of the let-7 family promotes de-differentiation of somatic cells to induced pluripotent stem cells (84).

In vitro phenotype of iPSC-derived cardiomyocytes. The phenotype of murine iPSC-CMs has been more extensively characterized at this point of time. The Martin group (82) has described the phenotype of cardiomyocytes generated from an miPSC line via EB differentiation, whereas the Yamashita group (95) obtained cardiomyocytes from three other mouse iPSCs lines by coculturing mesodermal miPSC derivatives with OP9 mouse stromal cells. In both cases, the resultant miPSC-CMs showed an unambiguous cardiac phenotype comparable to that of mESC-CMs. miPSC-CMs expressed expected cardiac markers, including $\alpha$-myosin heavy chain, cardiac troponin $\mathrm{T}$, and atrial natriuretic peptide $(82,95)$. iPSC cardiomyocytes displayed spontaneous rhythmic intracellular $\mathrm{Ca}(2+)$ fluctuations with amplitudes of $\mathrm{Ca}(2+)$ transients comparable to ES cell cardiomyocytes (82). Simultaneous $\mathrm{Ca}(2+)$ release within clusters of iPSC-derived cardiomyocytes indicated functional coupling of the cells. Electrophysiological studies with multielectrode arrays demonstrated functionality and presence of the $\beta$-adrenergic and muscarinic signaling cascade in these cells (82). They also exhibited spontaneous contractile activity that could be modulated by isoproterenol or carbachol, indicating intact neurohormonal signaling (82). Of some concern the Yamashita group (95) reported that prolonged in vitro culture of iPSC-CMs resulted in the occasional reexpression of reprogramming factors, including the protooncogene $\mathrm{c}-\mathrm{myc}$, a finding that reemphasizes the need for improved methods of reprogramming. More recently, Martinez et al. showed that iPSCs bioengineered without c-MYC still achieved highest stringency criteria for bona fide cardiogenesis enabling reprogrammed fibroblasts to yield de novo heart tissue compatible with native counterpart throughout embryological development and into adulthood (79). It has also been demonstrated that the cardiogenic potential of iPSCs is comparable to that of ES cells and that iPS-CMs possess all fundamental functional elements of a typical cardiac cell, including spontaneous beating, hormonal regulation, cardiac ion channel expression, and contractility (106). Lately, another group has extensively characterized murine iPSC-derived cardiomyocytes (61). They differentiated murine iPSCs to CMs in vitro and characterized them by RT-PCR, immunocytochemistry, and electrophysiology. As key markers of cardiac lineages, transcripts for Nkx2.5, $\alpha-\mathrm{MHC}, \mathrm{Mlc} 2 \mathrm{v}$, and cTnT could be identified. Immunocytochemical stainings revealed the presence of organized sarcomeric actinin but the absence of mature atrial natriuretic factor. They examined characteristics and developmental changes of action potentials, as well as functional hormonal regulation and sensitivity to channel blockers. In addition, they determined expression patterns and functionality of cardiac-specific voltage-gated $\mathrm{Na}+, \mathrm{Ca} 2+$, and $\mathrm{K}+$ channels at early and late differentiation stages and compared them with CMs derived from murine ESCs as well as with fetal CMs. These authors concluded that iPSCs give rise to functional CMs in vitro, with established hormonal regulation pathways and functionally expressed cardiac ion channels; CMs generated from iPSCs have a ventricular phenotype; and cardiac development of iPSCs is delayed compared with maturation of native fetal CMs and of ESC-derived CMs (61). This difference may reflect the incomplete reprogramming of iPSCs and should be critically considered in further studies to clarify the suitability of the iPS model for regenerative medicine of heart disorders.

The cardiac differentiation potential of human iPSCs has also been studied. Human iPSCs generated using OCT4, SOX2, NANOG, and LIN28 transgenes were compared to human embryonic stem (ES) cells (158). The iPS and ES cells were differentiated using the EB method. The time course of developing contracting EBs was comparable for the iPS and ES cell lines, although the absolute percentages of contracting EBs differed (158). RT-PCR analyses of iPS and ES cell-derived cardiomyocytes demonstrated similar cardiac gene expression patterns. The pluripotency genes OCT4 and NANOG were downregulated with cardiac differentiation, but the downregulation was blunted in the iPSC lines because of residual transgene expression. Proliferation of iPS and ES cellderived cardiomyocytes based on 5-bromodeoxyuridine labeling was similar, and immunocytochemistry of isolated cardiomyocytes revealed indistinguishable sarcomeric organizations. Electrophysiology studies indicated that iPSCs have a capacity like ES cells for differentiation into nodal-, atrial-, and ventricular-like phenotypes based on action potential characteristics (158). Both iPS and ES cell-derived cardiomyocytes exhibited responsiveness to $\beta$-adrenergic stimulation manifest by an increase in spontaneous rate and a decrease in action potential duration. They concluded that human iPSCs can differentiate into functional cardiomyocytes (158). Zwi et al. (161) have shown (1) that hiPSC-based EB differentiating system can give rise to cardiomyocytes with the appropriate molecular, structural, and functional properties; (2) that the temporal gene expression pattern associated with hiPS cardiomyogenesis involves expression of mesoderm- and cardiomesoderm-specific markers, followed by expression of cardiac-specific transcription factors and structural genes; (3) that this differentiating system is not limited to the generation of isolated cardiomyocytes but rather a functional cardiac syncytium is formed; and (4) that the hiPSCderived cardiac tissue can respond appropriately to adrenergic and muscarinic signals and can serve as a unique platform for drug testing. In another recent study using genetic fatemapping, the authors showed that Isl1+ multipotent cardiovascular progenitors can be generated from mouse iPSCs and spontaneously differentiate in all three cardiovascular lineages in vivo without teratoma (88). Moreover, they report the identification of human iPS-derived ISL1(+) progenitors with similar developmental potential (88).

Induced pluripotent stem cells in cardiac repair. The application of iPSCs in cardiac repair has only recently been investigated in animal models. Nelson et al. recently demonstrated that intramyocardial delivery of iPSCs in a murine model of myocardial infarction resulted in improvement in ejection fraction and attenuation of adverse remodeling at 4 
weeks (96). In this study, fibroblasts transduced with human stemness factors OCT3/4, SOX2, KLF4, and c-MYC converted into an ESC-like phenotype and demonstrated the ability to spontaneously assimilate into preimplantation host morula via diploid aggregation, unique to bona fide pluripotent cells. In utero, iPS-derived chimera executed differentiation programs to construct normal heart parenchyma patterning. The mixed cell populations derived from the EBs used in this study contributed to cardiac, smooth muscle, and endothelial cell types, suggesting that iPSCs might effect a more complete regeneration (96). Moreover, no tumors were identified in this small study.

However, iPSCs still have limitations in terms of their use for cardiac regeneration. It has already been mentioned that genome-integrating viral vectors used for reprogramming are known oncogenes, particularly c-Myc, Oct4, and Klf4, such that iPSCs thus generated are unlikely to be safe for clinical application. Solutions include methods to reprogram without viral integration such as plasmids or direct reprogramming protein delivery $(101,129,159)$. Second, the process of human iPSC generation by retroviral-mediated reprogramming is not very efficient (as low as $0.001 \%-0.01 \%$ ). Inhibition of p53mediated pathways and vitamin $C$ supplementation may enhance the generation of iPSCs $(29,39)$. It is also not clear whether human iPSC clone have complete nuclear reprogramming and incomplete reprogramming of somatic cells to iPSCs could result in impaired differentiation of iPSCs into the required cell type (154). Lastly, all pluripotent stem cells may cause teratoma formation and thus require careful regulation.

In summary, cell-based therapy for cardiac repair has shown definite improvement in ventricular function in animal models of ischemic heart disease. The mechanisms underlying the beneficial effects of cell transplantation still remain to be elucidated. It is clear that there is a lack of long term of engraftment of stem cells and the functional improvement may be related to paracrine effects. It is also exciting to speculate that stimulation of endogenous repair mechanisms may contribute to this effect. The future holds great promise and methods to improve cell survival and promote integration of transplanted cells with host cardiomyocytes are areas of intense research. Similarly, the development of iPSCs opens the door for replacing scar tissue through differentiation of transplanted iPSCs into new cardiomyocytes.

\section{Acknowledgments}

This work was supported by U.S. Public Health Service Grants HL50470, HL61353, and HL 67828. M.N.J was supported by AHA Greater Midwest Predoctoral Award \# $0810015 Z$.

\section{References}

1. Aasen T, Raya A, Barrero MJ, Garreta E, Consiglio A, Gonzalez F, Vassena R, Bilic J, Pekarik V, Tiscornia G, Edel $\mathrm{M}$, Boue S, and Izpisua Belmonte JC. Efficient and rapid generation of induced pluripotent stem cells from human keratinocytes. Nat Biotechnol 26: 1276-1284, 2008.

2. Abraham MR, Henrikson CA, Tung L, Chang MG, Aon M, Xue T, Li RA, O'Rourke B, and Marban E. Antiarrhythmic engineering of skeletal myoblasts for cardiac transplantation. Circ Res 97: 159-167, 2005.
3. Alhadlaq A and Mao JJ. Mesenchymal stem cells: isolation and therapeutics. Stem Cells Dev 13: 436-448, 2004.

4. Anderson D, Self T, Mellor IR, Goh G, Hill SJ, and Denning C. Transgenic enrichment of cardiomyocytes from human embryonic stem cells. Mol Ther 15: 2027-2036, 2007.

5. Anversa $P$ and Kajstura J. Ventricular myocytes are not terminally differentiated in the adult mammalian heart. Circ Res 83: 1-14, 1998.

6. Anversa $P$ and Nadal-Ginard B. Myocyte renewal and ventricular remodelling. Nature 415: 240-243, 2002.

7. Anversa P, Sussman MA, and Bolli R. Molecular genetic advances in cardiovascular medicine: focus on the myocyte. Circulation 109: 2832-2838, 2004.

8. Aoi T, Yae K, Nakagawa M, Ichisaka T, Okita K, Takahashi $\mathrm{K}$, Chiba T, and Yamanaka S. Generation of pluripotent stem cells from adult mouse liver and stomach cells. Science 321: 699-702, 2008.

9. Asahara T, Murohara T, Sullivan A, Silver M, van der Zee R, Li T, Witzenbichler B, Schatteman G, and Isner JM. Isolation of putative progenitor endothelial cells for angiogenesis. Science 275: 964-967, 1997.

10. Balsam LB, Wagers AJ, Christensen JL, Kofidis T, Weissman IL, and Robbins RC. Haematopoietic stem cells adopt mature haematopoietic fates in ischaemic myocardium. Nature 428: 668-673, 2004.

11. Barbash IM, Chouraqui P, Baron J, Feinberg MS, Etzion S, Tessone A, Miller L, Guetta E, Zipori D, Kedes LH, Kloner RA, and Leor J. Systemic delivery of bone marrow-derived mesenchymal stem cells to the infarcted myocardium: feasibility, cell migration, and body distribution. Circulation 108: 863-868, 2003.

12. Bartholomew A, Sturgeon C, Siatskas M, Ferrer K, McIntosh K, Patil S, Hardy W, Devine S, Ucker D, Deans R, Moseley A, and Hoffman R. Mesenchymal stem cells suppress lymphocyte proliferation in vitro and prolong skin graft survival in vivo. Exp Hematol 30: 42-48, 2002.

13. Bearzi C, Muller P, Amano K, Tang X-L, Loredo M, Mosna F, Gatti A, Esposito G, Leri A, Kajsutra J, Anversa P, Rimoldi $\mathrm{O}$, and Bolli R. Identification and characterization of cardiac stem cells in the pig heart. Circulation 114: II-125, 2006.

14. Bearzi C, Rota M, Hosoda T, Tillmanns J, Nascimbene A, De Angelis A, Yasuzawa-Amano S, Trofimova I, Siggins RW, Lecapitaine N, Cascapera S, Beltrami AP, D'Alessandro DA, Zias E, Quaini F, Urbanek K, Michler RE, Bolli R, Kajstura J, Leri A, and Anversa P. Human cardiac stem cells. Proc Natl Acad Sci USA 104: 14068-14073, 2007.

15. Beltrami AP, Barlucchi L, Torella D, Baker M, Limana F, Chimenti S, Kasahara H, Rota M, Musso E, Urbanek K, Leri A, Kajstura J, Nadal-Ginard B, and Anversa P. Adult cardiac stem cells are multipotent and support myocardial regeneration. Cell 114: 763-776, 2003.

16. Beltrami AP, Urbanek K, Kajstura J, Yan SM, Finato N, Bussani R, Nadal-Ginard B, Silvestri F, Leri A, Beltrami CA, and Anversa P. Evidence that human cardiac myocytes divide after myocardial infarction. New Engl J Med 344: 1750-1757, 2001.

17. Bergmann O, Bhardwaj RD, Bernard S, Zdunek S, BarnabeHeider F, Walsh S, Zupicich J, Alkass K, Buchholz BA, Druid $\mathrm{H}$, Jovinge $\mathrm{S}$, and Frisen J. Evidence for cardiomyocyte renewal in humans. Science 324: 98-102, 2009.

18. Bittner RE, Schofer C, Weipoltshammer K, Ivanova S, Streubel B, Hauser E, Freilinger M, Hoger H, Elbe-Burger $\mathrm{A}$, and Wachtler F. Recruitment of bone-marrow-derived 
cells by skeletal and cardiac muscle in adult dystrophic mdx mice. Anat Embryol 199: 391-396, 1999.

19. Caplan AI. Mesenchymal stem cells. J Orthop Res 9: 641650, 1991.

20. Cerisoli F, Chimenti I, Gaetani R, Barile L, and Frati G. Kitpositive cardiac stem cells (CSCs) can be generated in damaged heart from bone marrow-derived cells. Circulation 114: II-164, 2006.

21. Chen X, Wilson RM, Kubo H, Berretta RM, Harris DM, Zhang X, Jaleel N, MacDonnell SM, Bearzi C, Tillmanns J, Trofimova I, Hosoda T, Mosna F, Cribbs L, Leri A, Kajstura J, Anversa P, and Houser SR. Adolescent feline heart contains a population of small, proliferative ventricular myocytes with immature physiological properties. Circ Res 100: 536-544, 2007.

22. Chimenti C, Kajstura J, Torella D, Urbanek K, Heleniak H, Colussi C, Di Meglio F, Nadal-Ginard B, Frustaci A, Leri A, Maseri A, and Anversa P. Senescence and death of primitive cells and myocytes lead to premature cardiac aging and heart failure. Circ Res 93: 604-613, 2003.

23. Cowan CA, Atienza J, Melton DA, and Eggan K. Nuclear reprogramming of somatic cells after fusion with human embryonic stem cells. Science 309: 1369-1373, 2005.

24. Dai W, Hale SL, Martin BJ, Kuang JQ, Dow JS, Wold LE, and Kloner RA. Allogeneic mesenchymal stem cell transplantation in postinfarcted rat myocardium: short- and long-term effects. Circulation 112: 214-223, 2005.

25. Dawn B, Stein AB, Urbanek K, Rota M, Whang B, Rastaldo R, Torella D, Tang XL, Rezazadeh A, Kajstura J, Leri A, Hunt G, Varma J, Prabhu SD, Anversa P, and Bolli R. Cardiac stem cells delivered intravascularly traverse the vessel barrier, regenerate infarcted myocardium, and improve cardiac function. Proc Natl Acad Sci USA 102: 37663771, 2005.

26. Di Nicola M, Carlo-Stella C, Magni M, Milanesi M, Longoni PD, Matteucci P, Grisanti S, and Gianni AM. Human bone marrow stromal cells suppress T-lymphocyte proliferation induced by cellular or nonspecific mitogenic stimuli. Blood 99: 3838-3843, 2002.

27. Doetschman TC, Eistetter H, Katz M, Schmidt W, and Kemler R. The in vitro development of blastocyst-derived embryonic stem cell lines: formation of visceral yolk sac, blood islands and myocardium. J Embryol Exp Morphol 87: 27-45, 1985.

28. Dowell JD, Rubart M, Pasumarthi KB, Soonpaa MH, and Field LJ. Myocyte and myogenic stem cell transplantation in the heart. Cardiovasc Res 58: 336-350, 2003

29. Esteban MA, Wang T, Qin B, Yang J, Qin D, Cai J, Li W, Weng Z, Chen J, Ni S, Chen K, Li Y, Liu X, Xu J, Zhang S, Li F, He W, Labuda K, Song Y, Peterbauer A, Wolbank S, Redl $\mathrm{H}$, Zhong M, Cai D, Zeng L, and Pei D. Vitamin C enhances the generation of mouse and human induced pluripotent stem cells. Cell Stem Cell 6: 71-79, 2010.

30. Fukuda K. Molecular characterization of regenerated cardiomyocytes derived from adult mesenchymal stem cells. Congenital Anom 42: 1-9, 2002.

31. Fukuda K. Use of adult marrow mesenchymal stem cells for regeneration of cardiomyocytes. Bone Marrow Transplant 32 Suppl 1: S25-S27, 2003.

32. Graichen $\mathrm{R}, \mathrm{Xu} X$, Braam SR, Balakrishnan T, Norfiza $S$, Sieh S, Soo SY, Tham SC, Mummery C, Colman A, Zweigerdt R, and Davidson BP. Enhanced cardiomyogenesis of human embryonic stem cells by a small molecular inhibitor of p38 MAPK. Differentiation 76: 357-370, 2008.
33. Haider HK, Idris NM, Kim HW, Ahmed RP, Shujia J, and Ashraf M. MicroRNA-21 is a key determinant in IL11/ STAT-3 anti-apoptotic signaling pathway in preconditioning of skeletal myoblasts. Cardiovasc Res 88: 168-178, 2010.

34. Hakuno D, Fukuda K, Makino S, Konishi F, Tomita Y, Manabe T, Suzuki Y, Umezawa A, and Ogawa S. Bone marrow-derived regenerated cardiomyocytes (CMG Cells) express functional adrenergic and muscarinic receptors. Circulation 105: 380-386, 2002.

35. Hattori F, Chen H, Yamashita H, Tohyama S, Satoh YS, Yuasa S, Li W, Yamakawa H, Tanaka T, Onitsuka T, Shimoji K, Ohno Y, Egashira T, Kaneda R, Murata M, Hidaka K, Morisaki T, Sasaki E, Suzuki T, Sano M, Makino S, Oikawa S, and Fukuda K. Nongenetic method for purifying stem cell-derived cardiomyocytes. Nat Methods 7: 61-66, 2010.

36. Haynesworth SE, Baber MA, and Caplan AI. Cell surface antigens on human marrow-derived mesenchymal cells are detected by monoclonal antibodies. Bone 13: 69-80, 1992

37. He KL, Yi GH, Sherman W, Zhou H, Zhang GP, Gu A, Kao R, Haimes HB, Harvey J, Roos E, White D, Taylor DA, Wang J, and Burkhoff D. Autologous skeletal myoblast transplantation improved hemodynamics and left ventricular function in chronic heart failure dogs. J Heart Lung Transplant 24: 1940-1949, 2005.

38. Hirata $Y$, Sata M, Motomura N, Takanashi M, Suematsu $Y$, Ono M, and Takamoto S. Human umbilical cord blood cells improve cardiac function after myocardial infarction. Biochem Biophys Res Commun 327: 609-614, 2005.

39. Hong $\mathrm{H}$, Takahashi $\mathrm{K}$, Ichisaka $\mathrm{T}$, Aoi $\mathrm{T}$, Kanagawa $\mathrm{O}$, Nakagawa M, Okita K, and Yamanaka S. Suppression of induced pluripotent stem cell generation by the p53-p21 pathway. Nature 460: 1132-1135, 2009.

40. Hosoda T, Bearzi C, Amano S, Rota M, Valentini S, Delucchi F, Tillmanns J, Nascimbene A, Angelis AD, Siggins RW, Zias E, Quaini F, Urbanek K, Leri A, Kajstura J, Bolli R, and Anversa P. Human cardiac progenitor cells regenerate cardiomyocytes and coronary vessels repairing the infarcted myocardium. Circulation 114: II-51, 2006.

41. Hsieh PC, Segers VF, Davis ME, MacGillivray C, Gannon J, Molkentin JD, Robbins J, and Lee RT. Evidence from a genetic fate-mapping study that stem cells refresh adult mammalian cardiomyocytes after injury. Nat Med 13: 970974, 2007.

42. Huber I, Itzhaki I, Caspi O, Arbel G, Tzukerman M, Gepstein A, Habib M, Yankelson L, Kehat I, and Gepstein L. Identification and selection of cardiomyocytes during human embryonic stem cell differentiation. FASEB J 21: 2551-2563, 2007.

43. Jackson KA, Majka SM, Wang H, Pocius J, Hartley CJ, Majesky MW, Entman ML, Michael LH, Hirschi KK, and Goodell MA. Regeneration of ischemic cardiac muscle and vascular endothelium by adult stem cells. J Clin Invest 107: 1395-1402, 2001.

44. Jain M, DerSimonian H, Brenner DA, Ngoy S, Teller P, Edge AS, Zawadzka A, Wetzel K, Sawyer DB, Colucci WS, Apstein CS, and Liao R. Cell therapy attenuates deleterious ventricular remodeling and improves cardiac performance after myocardial infarction. Circulation 103: 1920-1927, 2001.

45. Jameel MN, Li Q, Mansoor A, Qiang X, Sarver A, Wang X, Swingen $C$, and Zhang J. Long term functional improvement and gene expression changes after bone marrow derived multipotent progenitor cell transplantation in 
myocardial infarction. Am J Physiol 298: H1348-H1356, 2010.

46. Johnston P, Sasano T, Mills K, Youssef A, Pittenger M, Lange $\mathrm{R}$, and Marban E. Isolation, expansion and delivery of cardiac derived stem cells in a porcine model of myocardial infarction. Circulation 114: II-125, 2006.

47. Kajstura J, Urbanek K, Perl S, Hosoda T, Zheng H, Ogorek B, Ferreira-Martins J, Goichberg P, Rondon C, D'Amario D, Rota M, Del Monte F, Orlic D, Tisdale J, Leri A, and Anversa P. Cardiomyogenesis in the adult human heart. Circ Res 107: 305-315, 2010.

48. Kajstura J, Urbanek K, Rota M, Bearzi C, Hosoda T, Bolli R, Anversa $\mathrm{P}$, and Leri A. Cardiac stem cells and myocardial disease. J Mol Cell Cardiol 45: 505-513, 2008.

49. Kattman SJ, Huber TL, and Keller GM. Multipotent flk-1+ cardiovascular progenitor cells give rise to the cardiomyocyte, endothelial, and vascular smooth muscle lineages. Dev Cell 11: 723-732, 2006.

50. Kawai T, Takahashi T, Esaki M, Ushikoshi H, Nagano S, Fujiwara H, and Kosai K. Efficient cardiomyogenic differentiation of embryonic stem cell by fibroblast growth factor 2 and bone morphogenetic protein 2. Circ J 68: 691-702, 2004.

51. Kawamoto A, Tkebuchava T, Yamaguchi J, Nishimura $H$, Yoon YS, Milliken C, Uchida S, Masuo O, Iwaguro H, Ma H, Hanley A, Silver M, Kearney M, Losordo DW, Isner JM, and Asahara T. Intramyocardial transplantation of autologous endothelial progenitor cells for therapeutic neovascularization of myocardial ischemia. Circulation 107: 461-468, 2003.

52. Kehat I, Kenyagin-Karsenti D, Snir M, Segev H, Amit M, Gepstein A, Livne E, Binah O, Itskovitz-Eldor J, and Gepstein L. Human embryonic stem cells can differentiate into myocytes with structural and functional properties of cardiomyocytes. J Clin Invest 108: 407-414, 2001.

53. Kehat I, Khimovich L, Caspi O, Gepstein A, Shofti R, Arbel G, Huber I, Satin J, Itskovitz-Eldor J, and Gepstein L. Electromechanical integration of cardiomyocytes derived from human embryonic stem cells. Nat Biotechnol 22: 12821289, 2004.

54. Kim BO, Tian H, Prasongsukarn K, Wu J, Angoulvant D, Wnendt S, Muhs A, Spitkovsky D, and Li RK. Cell transplantation improves ventricular function after a myocardial infarction: a preclinical study of human unrestricted somatic stem cells in a porcine model. Circulation 112: I96104, 2005.

55. Kim JB, Sebastiano V, Wu G, Arauzo-Bravo MJ, Sasse P, Gentile L, Ko K, Ruau D, Ehrich M, van den Boom D, Meyer J, Hubner K, Bernemann C, Ortmeier C, Zenke M, Fleischmann BK, Zaehres H, and Scholer HR. Oct4-induced pluripotency in adult neural stem cells. Cell 136: 411-419, 2009.

56. Kocher AA, Schuster MD, Szabolcs MJ, Takuma S, Burkhoff D, Wang J, Homma S, Edwards NM, and Itescu S. Neovascularization of ischemic myocardium by human bone-marrow-derived angioblasts prevents cardiomyocyte apoptosis, reduces remodeling and improves cardiac function. Nat Med 7: 430-436, 2001.

57. Kogler G, Sensken S, Airey JA, Trapp T, Muschen M, Feldhahn N, Liedtke S, Sorg RV, Fischer J, Rosenbaum C, Greschat S, Knipper A, Bender J, Degistirici O, Gao J, Caplan AI, Colletti EJ, Almeida-Porada G, Muller HW, Zanjani E, and Wernet P. A new human somatic stem cell from placental cord blood with intrinsic pluripotent differentiation potential. J Exp Med 200: 123-135, 2004.
58. Koh GY, Klug MG, Soonpaa MH, and Field LJ. Differentiation and long-term survival of $\mathrm{C} 2 \mathrm{C} 12$ myoblast grafts in heart. J Clin Invest 92: 1548-1554, 1993.

59. Kolossov E, Bostani T, Roell W, Breitbach M, Pillekamp F, Nygren JM, Sasse P, Rubenchik O, Fries JW, Wenzel D, Geisen C, Xia Y, Lu Z, Duan Y, Kettenhofen R, Jovinge S, Bloch W, Bohlen H, Welz A, Hescheler J, Jacobsen SE, and Fleischmann BK. Engraftment of engineered ES cell-derived cardiomyocytes but not BM cells restores contractile function to the infarcted myocardium. J Exp Med 203: 23152327, 2006.

60. Kucia M, Dawn B, Hunt G, Guo Y, Wysoczynski M, Majka M, Ratajczak J, Rezzoug F, Ildstad ST, Bolli R, and Ratajczak MZ. Cells expressing early cardiac markers reside in the bone marrow and are mobilized into the peripheral blood after myocardial infarction. Circ Res 95: 1191-1199, 2004.

61. Kuzmenkin A, Liang H, Xu G, Pfannkuche K, Eichhorn H, Fatima A, Luo H, Saric T, Wernig M, Jaenisch R, and Hescheler J. Functional characterization of cardiomyocytes derived from murine induced pluripotent stem cells in vitro. FASEB J 23: 4168-4180, 2009.

62. Laflamme MA, Chen KY, Naumova AV, Muskheli V, Fugate JA, Dupras SK, Reinecke $\mathrm{H}, \mathrm{Xu} \mathrm{C}$, Hassanipour M, Police S, O'Sullivan C, Collins L, Chen Y, Minami E, Gill EA, Ueno S, Yuan C, Gold J, and Murry CE. Cardiomyocytes derived from human embryonic stem cells in prosurvival factors enhance function of infarcted rat hearts. Nat Biotechnol 25: 1015-1024, 2007.

63. Laflamme MA, Gold J, Xu C, Hassanipour M, Rosler E, Police S, Muskheli V, and Murry CE. Formation of human myocardium in the rat heart from human embryonic stem cells. Am J Pathol 167: 663-671, 2005.

64. Laugwitz KL, Moretti A, Lam J, Gruber P, Chen Y, Woodard S, Lin LZ, Cai CL, Lu MM, Reth M, Platoshyn O, Yuan JX, Evans S, and Chien KR. Postnatal isl1+ cardioblasts enter fully differentiated cardiomyocyte lineages. Nature 433: 647-653, 2005.

65. Le Blanc K, Tammik C, Rosendahl K, Zetterberg E, and Ringden O. HLA expression and immunologic properties of differentiated and undifferentiated mesenchymal stem cells. Exp Hematol 31: 890-896, 2003.

66. Le Blanc K, Tammik L, Sundberg B, Haynesworth SE, and Ringden $\mathrm{O}$. Mesenchymal stem cells inhibit and stimulate mixed lymphocyte cultures and mitogenic responses independently of the major histocompatibility complex. Scand J Immunol 57: 11-20, 2003.

67. Leobon B, Garcin I, Menasche P, Vilquin JT, Audinat E, and Charpak S. Myoblasts transplanted into rat infarcted myocardium are functionally isolated from their host. Proc Natl Acad Sci USA 100: 7808-7811, 2003.

68. Leri A, Kajstura J, and Anversa P. Cardiac stem cells and mechanisms of myocardial regeneration. Physiol Rev 85: 1373-1416, 2005.

69. Lewis ID and Verfaillie CM. Multi-lineage expansion potential of primitive hematopoietic progenitors: superiority of umbilical cord blood compared to mobilized peripheral blood. Exp Hematol 28: 1087-1095, 2000.

70. Lin Y, Weisdorf DJ, Solovey A, and Hebbel RP. Origins of circulating endothelial cells and endothelial outgrowth from blood. J Clin Invest 105: 71-77, 2000.

71. Linke A, Muller P, Nurzynska D, Casarsa C, Torella D, Nascimbene A, Castaldo C, Cascapera S, Bohm M, Quaini F, Urbanek K, Leri A, Hintze TH, Kajstura J, and Anversa P. 
Stem cells in the dog heart are self-renewing, clonogenic, and multipotent and regenerate infarcted myocardium, improving cardiac function. Proc Natl Acad Sci USA 102: 8966-8971, 2005.

72. Liu J, Hu Q, Wang Z, Xu C, Wang X, Gong G, Mansoor A, Lee J, Hou M, Zeng L, Zhang JR, Jerosch-Herold M, Guo T, Bache RJ, and Zhang J. Autologous stem cell transplantation for myocardial repair. Am J Physiol 287: H501-H511, 2004.

73. Lowry WE, Richter L, Yachechko R, Pyle AD, Tchieu J, Sridharan R, Clark AT, and Plath K. Generation of human induced pluripotent stem cells from dermal fibroblasts. Proc Natl Acad Sci USA 105: 2883-2888, 2008.

74. Ma N, Stamm C, Kaminski A, Li W, Kleine HD, MullerHilke B, Zhang L, Ladilov Y, Egger D, and Steinhoff G. Human cord blood cells induce angiogenesis following myocardial infarction in NOD/scid-mice. Cardiovasc Res 66: 45-54, 2005.

75. MacLellan WR and Schneider MD. Genetic dissection of cardiac growth control pathways. Annu Rev Physiol 62: 289-319, 2000.

76. Majumdar MK, Keane-Moore M, Buyaner D, Hardy WB, Moorman MA, McIntosh KR, and Mosca JD. Characterization and functionality of cell surface molecules on human mesenchymal stem cells. J Biomed Sci 10: 228-241, 2003.

77. Makino S, Fukuda K, Miyoshi S, Konishi F, Kodama H, Pan J, Sano M, Takahashi T, Hori S, Abe H, Hata J, Umezawa A, and Ogawa $\mathrm{S}$. Cardiomyocytes can be generated from marrow stromal cells in vitro. J Clin Invest 103: 697-705, 1999.

78. Martin CM, Meeson AP, Robertson SM, Hawke TJ, Richardson JA, Bates S, Goetsch SC, Gallardo TD, and Garry DJ. Persistent expression of the ATP-binding cassette transporter, Abcg2, identifies cardiac SP cells in the developing and adult heart. Dev Biol 265: 262-275, 2004.

79. Martinez-Fernandez A, Nelson TJ, Yamada S, Reyes S, Alekseev AE, Perez-Terzic C, Ikeda Y, and Terzic A. iPS programmed without c-MYC yield proficient cardiogenesis for functional heart chimerism. Circ Res 105: 648-656, 2009.

80. Masuda $\mathrm{H}$ and Asahara T. Post-natal endothelial progenitor cells for neovascularization in tissue regeneration. Cardiovasc Res 58: 390-398, 2003.

81. Matsura K, Nagai T, Nishigaki N, Oyama T, Nishi J, Wada H, Sano M, Toko H, Akazawa H, Sato T, Nakaya H, Kasanuki H, and Komuro I. Adult cardiac Sca-1-positive cells differentiate into beating cardiomyocytes. J Biol Chem 279: 11384-11391, 2004.

82. Mauritz C, Schwanke K, Reppel M, Neef S, Katsirntaki K, Maier LS, Nguemo F, Menke S, Haustein M, Hescheler J, Hasenfuss G, and Martin U. Generation of functional murine cardiac myocytes from induced pluripotent stem cells. Circulation 118: 507-517, 2008.

83. Mayani H and Lansdorp PM. Biology of human umbilical cord blood-derived hematopoietic stem/progenitor cells. Stem Cells 16: 153-165, 1998.

84. Melton C, Judson RL, and Blelloch R. Opposing microRNA families regulate self-renewal in mouse embryonic stem cells. Nature 463: 621-626, 2010.

85. Messina E, De Angelis L, Frati G, Morrone S, Chimenti S, Fiordaliso F, Salio M, Battaglia M, Latronico MV, Coletta M, Vivarelli E, Frati L, Cossu G, and Giacomello A. Isolation and expansion of adult cardiac stem cells from human and murine heart. Circ Res 95: 911-921, 2004.
86. Min JY, Yang Y, Converso KL, Liu L, Huang Q, Morgan JP, and Xiao YF. Transplantation of embryonic stem cells improves cardiac function in postinfarcted rats. J Appl Physiol 92: 288-296, 2002.

87. Minguell JJ, Erices A, and Conget P. Mesenchymal stem cells. Exp Biol Med 226: 507-520, 2001.

88. Moretti A, Bellin M, Jung CB, Thies TM, Takashima Y, Bernshausen A, Schiemann M, Fischer S, Moosmang S, Smith AG, Lam JT, and Laugwitz KL. Mouse and human induced pluripotent stem cells as a source for multipotent Isl1+ cardiovascular progenitors. FASEB J 2009.

89. Moretti A, Caron L, Nakano A, Lam JT, Bernshausen A, Chen Y, Qyang Y, Bu L, Sasaki M, Martin-Puig S, Sun Y, Evans SM, Laugwitz KL, and Chien KR. Multipotent embryonic isl1+ progenitor cells lead to cardiac, smooth muscle, and endothelial cell diversification. Cell 127: 11511165, 2006.

90. Mouquet F, Pfister O, Jain M, Oikonomopoulos A, Ngoy S, Summer R, Fine A, and Liao R. Restoration of cardiac progenitor cells after myocardial infarction by self-proliferation and selective homing of bone marrow-derived stem cells. Circ Res 97: 1090-1092, 2005.

91. Murohara T, Ikeda H, Duan J, Shintani S, Sasaki K, Eguchi $\mathrm{H}$, Onitsuka I, Matsui K, and Imaizumi T. Transplanted cord blood-derived endothelial precursor cells augment postnatal neovascularization. J Clin Invest 105: 1527-1536, 2000.

92. Murry CE, Soonpaa $\mathrm{MH}$, Reinecke $\mathrm{H}$, Nakajima $\mathrm{H}$, Nakajima HO, Rubart M, Pasumarthi KB, Virag JI, Bartelmez SH, Poppa V, Bradford G, Dowell JD, Williams DA, and Field LJ. Haematopoietic stem cells do not transdifferentiate into cardiac myocytes in myocardial infarcts. Nature 428: 664-668, 2004.

93. Nadal-Ginard B, Kajstura J, Leri A, and Anversa P. Myocyte death, growth, and regeneration in cardiac hypertrophy and failure. Circ Res 92: 139-150, 2003.

94. Nakagawa M, Koyanagi M, Tanabe K, Takahashi K, Ichisaka T, Aoi T, Okita K, Mochiduki Y, Takizawa N, and Yamanaka S. Generation of induced pluripotent stem cells without Myc from mouse and human fibroblasts. Nat Biotechnol 26: 101-106, 2008.

95. Narazaki G, Uosaki H, Teranishi M, Okita K, Kim B, Matsuoka S, Yamanaka S, and Yamashita JK. Directed and systematic differentiation of cardiovascular cells from mouse induced pluripotent stem cells. Circulation 118: 498506, 2008.

96. Nelson TJ, Martinez-Fernandez A, Yamada S, Perez-Terzic C, Ikeda Y, and Terzic A. Repair of acute myocardial infarction by human stemness factors induced pluripotent stem cells. Circulation 120: 408-416, 2009.

97. Niagara MI, Haider H, Jiang S, and Ashraf M. Pharmacologically preconditioned skeletal myoblasts are resistant to oxidative stress and promote angiomyogenesis via release of paracrine factors in the infarcted heart. Circ Res 100: 545$555,2007$.

98. Nussbaum J, Minami E, Laflamme MA, Virag JA, Ware CB, Masino A, Muskheli V, Pabon L, Reinecke H, and Murry CE. Transplantation of undifferentiated murine embryonic stem cells in the heart: teratoma formation and immune response. FASEB J 21: 1345-1357, 2007.

99. Oh H, Bradfute SB, Gallardo TD, Nakamura T, Gaussin V, Mishina Y, Pocius J, Michael LH, Behringer RR, Garry DJ, Entman ML, and Schneider MD. Cardiac progenitor cells from adult myocardium: homing, differentiation, and fusion 
after infarction. Proc Natl Acad Sci USA 100: 12313-12318, 2003.

100. Okita K, Ichisaka T, and Yamanaka S. Generation of germline-competent induced pluripotent stem cells. Nature 448: 313-317, 2007.

101. Okita K, Nakagawa M, Hyenjong H, Ichisaka T, and Yamanaka S. Generation of mouse induced pluripotent stem cells without viral vectors. Science 322: 949-953, 2008.

102. Orlic D, Kajstura J, Chimenti S, Jakoniuk I, Anderson SM, Li B, Pickel J, McKay R, Nadal-Ginard B, Bodine DM, Leri A, and Anversa P. Bone marrow cells regenerate infarcted myocardium. Nature 410: 701-705, 2001.

103. Park IH, Arora N, Huo H, Maherali N, Ahfeldt T, Shimamura A, Lensch MW, Cowan C, Hochedlinger K, and Daley GQ. Disease-specific induced pluripotent stem cells. Cell 134: 877-886, 2008.

104. Park IH, Zhao R, West JA, Yabuuchi A, Huo H, Ince TA, Lerou PH, Lensch MW, and Daley GQ. Reprogramming of human somatic cells to pluripotency with defined factors. Nature 451: 141-146, 2008.

105. Passier R, Oostwaard DW, Snapper J, Kloots J, Hassink RJ, Kuijk E, Roelen B, de la Riviere AB, and Mummery C. Increased cardiomyocyte differentiation from human embryonic stem cells in serum-free cultures. Stem Cells 23: 772780, 2005.

106. Pfannkuche $K$, Liang $H$, Hannes T, Xi J, Fatima A, Nguemo F, Matzkies M, Wernig M, Jaenisch R, Pillekamp F, Halbach M, Schunkert H, Saric T, Hescheler J, and Reppel M. Cardiac myocytes derived from murine reprogrammed fibroblasts: intact hormonal regulation, cardiac ion channel expression and development of contractility. Cell Physiol Biochem 24: 73-86, 2009.

107. Pfister O, Mouquet F, Jain M, Summer R, Helmes M, Fine A, Colucci WS, and Liao R. CD31- but Not CD31+ cardiac side population cells exhibit functional cardiomyogenic differentiation. Circ Res 97: 52-61, 2005.

108. Phinney DG, Kopen G, Righter W, Webster S, Tremain N, and Prockop DJ. Donor variation in the growth properties and osteogenic potential of human marrow stromal cells. $J$ Cell Biochem 75: 424-436, 1999.

109. Pittenger MF, Mackay AM, Beck SC, Jaiswal RK, Douglas R, Mosca JD, Moorman MA, Simonetti DW, Craig S, and Marshak DR. Multilineage potential of adult human mesenchymal stem cells. Science 284: 143-147, 1999.

110. Pittenger MF and Martin BJ. Mesenchymal stem cells and their potential as cardiac therapeutics. Circ Res 95: 9-20, 2004.

111. Prockop DJ. Marrow stromal cells as stem cells for nonhematopoietic tissues. Science 276: 71-74, 1997.

112. Quaini F, Urbanek K, Beltrami AP, Finato N, Beltrami CA, Nadal-Ginard B, Kajstura J, Leri A, and Anversa P. Chimerism of the transplanted heart. New Engl J Med 346: 5-15, 2002.

113. Reinecke H, MacDonald GH, Hauschka SD, and Murry CE. Electromechanical coupling between skeletal and cardiac muscle. Implications for infarct repair. J Cell Biol 149: 731740, 2000.

114. Roell W, Lewalter T, Sasse P, Tallini YN, Choi BR, Breitbach M, Doran R, Becher UM, Hwang SM, Bostani T, von Maltzahn J, Hofmann A, Reining S, Eiberger B, Gabris B, Pfeifer A, Welz A, Willecke K, Salama G, Schrickel JW, Kotlikoff MI, and Fleischmann BK. Engraftment of connexin 43-expressing cells prevents post-infarct arrhythmia. Nature 450: 819-824, 2007.
115. Rota M, Kajstura J, Hosoda T, Bearzi C, Vitale S, Esposito G, Iaffaldano G, Padin-Iruegas ME, Gonzalez A, Rizzi R, Small N, Muraski J, Alvarez R, Chen X, Urbanek K, Bolli R, Houser SR, Leri A, Sussman MA, and Anversa P. Bone marrow cells adopt the cardiomyogenic fate in vivo. Proc Natl Acad Sci USA 104: 17783-17788, 2007.

116. Rubart M and Field LJ. Cardiac regeneration: repopulating the heart. Annu Rev Physiol 68: 29-49, 2006.

117. Ryan JM, Barry FP, Murphy JM, and Mahon BP. Mesenchymal stem cells avoid allogeneic rejection. J Inflamm 2: 8, 2005.

118. Satin J, Itzhaki I, Rapoport S, Schroder EA, Izu L, Arbel G, Beyar R, Balke CW, Schiller J, and Gepstein L. Calcium handling in human embryonic stem cell-derived cardiomyocytes. Stem Cells 26: 1961-1972, 2008.

119. Shi Y, Desponts C, Do JT, Hahm HS, Scholer HR, and Ding $\mathrm{S}$. Induction of pluripotent stem cells from mouse embryonic fibroblasts by Oct4 and Klf4 with small-molecule compounds. Cell Stem Cell 3: 568-574, 2008.

120. Silva GV, Litovsky S, Assad JA, Sousa AL, Martin BJ, Vela D, Coulter SC, Lin J, Ober J, Vaughn WK, Branco RV, Oliveira EM, He R, Geng YJ, Willerson JT, and Perin EC. Mesenchymal stem cells differentiate into an endothelial phenotype, enhance vascular density, and improve heart function in a canine chronic ischemia model. Circulation 111: 150-156, 2005.

121. Singla DK, Hacker TA, Ma L, Douglas PS, Sullivan R, Lyons GE, and Kamp TJ. Transplantation of embryonic stem cells into the infarcted mouse heart: formation of multiple cell types. J Mol Cell Cardiol 40: 195-200, 2006.

122. Singla DK, Lyons GE, and Kamp TJ. Transplanted embryonic stem cells following mouse myocardial infarction inhibit apoptosis and cardiac remodeling. Am J Physiol 293: H1308-H1314, 2007.

123. Singla DK and McDonald DE. Factors released from embryonic stem cells inhibit apoptosis of H9c2 cells. Am J Physiol 293: H1590-H1595, 2007.

124. Singla DK, Singla RD, and McDonald DE. Factors released from embryonic stem cells inhibit apoptosis in $\mathrm{H} 9 \mathrm{c} 2$ cells through PI3K/Akt but not ERK pathway. Am J Physiol 295: H907-H913, 2008.

125. Singla DK and Sun B. Transforming growth factor-beta2 enhances differentiation of cardiac myocytes from embryonic stem cells. Biochem Biophys Res Commun 332: 135-141, 2005.

126. Smith RR, Barile L, Cho HC, Leppo MK, Hare JM, Messina E, Giacomello A, Abraham MR, and Marban E. Regenerative potential of cardiosphere-derived cells expanded from percutaneous endomyocardial biopsy specimens. Circulation 115: 896-908, 2007.

127. Soonpaa MH and Field LJ. Survey of studies examining mammalian cardiomyocyte DNA synthesis. Circ Res 83: 1526, 1998.

128. Stadtfeld M, Brennand $\mathrm{K}$, and Hochedlinger K. Reprogramming of pancreatic beta cells into induced pluripotent stem cells. Curr Biol 18: 890-894, 2008.

129. Stadtfeld M, Nagaya M, Utikal J, Weir G, and Hochedlinger K. Induced pluripotent stem cells generated without viral integration. Science 322: 945-949, 2008.

130. Sussman MA and Anversa P. Myocardial aging and senescence: where have the stem cells gone? Annu Rev Physiol 66: 29-48, 2004.

131. Suzuki G, Iyer V, Cimato T, and Canty JM Jr. Pravastatin improves function in hibernating myocardium by mobilizing 
CD133+ and cKit+ bone marrow progenitor cells and promoting myocytes to reenter the growth phase of the cardiac cell cycle. Circ Res 104: 255-264, 210p following 264, 2009.

132. Tada M, Takahama Y, Abe K, Nakatsuji N, and Tada T. Nuclear reprogramming of somatic cells by in vitro hybridization with ES cells. Curr Biol 11: 1553-1558, 2001.

133. Takahashi K, Tanabe K, Ohnuki M, Narita M, Ichisaka T, Tomoda K, and Yamanaka S. Induction of pluripotent stem cells from adult human fibroblasts by defined factors. Cell 131: 861-872, 2007

134. Takahashi $\mathrm{K}$ and Yamanaka S. Induction of pluripotent stem cells from mouse embryonic and adult fibroblast cultures by defined factors. Cell 126: 663-676, 2006.

135. Tang XL, Rokosh G, Sanganalmath SK, Yuan F, Sato H, Mu J, Dai S, Li C, Chen N, Peng Y, Dawn B, Hunt G, Leri A, Kajstura J, Tiwari S, Shirk G, Anversa P, and Bolli R. Intracoronary administration of cardiac progenitor cells alleviates left ventricular dysfunction in rats with a 30-day-old infarction. Circulation 121: 293-305, 2010.

136. Taylor DA, Atkins BZ, Hungspreugs P, Jones TR, Reedy MC, Hutcheson KA, Glower DD, and Kraus WE. Regenerating functional myocardium: improved performance after skeletal myoblast transplantation. Nat Med 4: 929-933, 1998.

137. Thomson JA, Itskovitz-Eldor J, Shapiro SS, Waknitz MA, Swiergiel JJ, Marshall VS, and Jones JM. Embryonic stem cell lines derived from human blastocysts. Science 282: 1145-1147, 1998.

138. Tomita S, Li RK, Weisel RD, Mickle DA, Kim EJ, Sakai T, and Jia ZQ. Autologous transplantation of bone marrow cells improves damaged heart function. Circulation 100: II247-II256, 1999.

139. Tomita S, Nakatani T, Fukuhara S, Morisaki T, Yutani C, and Kitamura S. Bone marrow stromal cells contract synchronously with cardiomyocytes in a coculture system. Jpn J Thorac Cardiovasc Surg 50: 321-324, 2002.

140. Torella D, Elliso GM, Karakikes I, Galuppo V, Serio DD, Onorati F, Mastroroberto P, Renzulli A, Indolfi C, and Nadal-Ginard B. Biological properties and regenerative potential, in vitro and in vivo, of human cardiac stem cells isolated from each of the four chambers of the adult human heart. Circulation 114: II-87, 2006.

141. Tse WT, Pendleton JD, Beyer WM, Egalka MC, and Guinan EC. Suppression of allogeneic T-cell proliferation by human marrow stromal cells: implications in transplantation. Transplantation 75: 389-397, 2003.

142. Urbanek K, Rota M, Cascapera S, Bearzi C, Nascimbene A, De Angelis A, Hosoda T, Chimenti S, Baker M, Limana F, Nurzynska D, Torella D, Rotatori F, Rastaldo R, Musso E, Quaini F, Leri A, Kajstura J, and Anversa P. Cardiac stem cells possess growth factor-receptor systems that after activation regenerate the infarcted myocardium, improving ventricular function and long-term survival. Circ Res 97: 663-673, 2005.

143. Urbanek K, Torella D, Sheikh F, De Angelis A, Nurzynska D, Silvestri F, Beltrami CA, Bussani R, Beltrami AP, Quaini F, Bolli R, Leri A, Kajstura J, and Anversa P. Myocardial regeneration by activation of multipotent cardiac stem cells in ischemic heart failure. Proc Natl Acad Sci USA 102: 8692 8697, 2005.

144. Wang JS, Shum-Tim D, Chedrawy E, and Chiu RC. The coronary delivery of marrow stromal cells for myocardial regeneration: pathophysiologic and therapeutic implications. J Thorac Cardiovasc Surg 122: 699-705, 2001.

145. Wang $X, \mathrm{Hu} Q$, Nakamura $Y$, Lee J, Zhang G, From AH, and Zhang J. The role of the sca-1+/CD31- cardiac progenitor cell population in postinfarction left ventricular remodeling. Stem Cells 24: 1779-1788, 2006.

146. Wang X, Jameel MN, Li Q, Mansoor A, Qiang X, Swingen C, Panetta C, and Zhang J. Stem cells for myocardial repair with use of a transarterial catheter. Circulation 120: S238S246, 2009.

147. Weir RA and McMurray JJ. Epidemiology of heart failure and left ventricular dysfunction after acute myocardial infarction. Curr Heart Fail Rep 3: 175-180, 2006.

148. Wernig M, Meissner A, Foreman R, Brambrink T, Ku M, Hochedlinger $\mathrm{K}$, Bernstein $\mathrm{BE}$, and Jaenisch R. In vitro reprogramming of fibroblasts into a pluripotent ES-cell-like state. Nature 448: 318-324, 2007.

149. Wilmut I, Schnieke AE, McWhir J, Kind AJ, and Campbell $\mathrm{KH}$. Viable offspring derived from fetal and adult mammalian cells. Nature 385: 810-813, 1997.

150. Wobus AM, Guan K, Yang HT, and Boheler KR. Embryonic stem cells as a model to study cardiac, skeletal muscle, and vascular smooth muscle cell differentiation. Methods Mol Biol 185: 127-156, 2002.

151. Wu SM, Fujiwara Y, Cibulsky SM, Clapham DE, Lien CL, Schultheiss TM, and Orkin SH. Developmental origin of a bipotential myocardial and smooth muscle cell precursor in the mammalian heart. Cell 127: 1137-1150, 2006.

152. Xu C, Police S, Rao N, and Carpenter MK. Characterization and enrichment of cardiomyocytes derived from human embryonic stem cells. Circ Res 91: 501-508, 2002.

153. Xue T, Cho HC, Akar FG, Tsang SY, Jones SP, Marban E, Tomaselli GF, and Li RA. Functional integration of electrically active cardiac derivatives from genetically engineered human embryonic stem cells with quiescent recipient ventricular cardiomyocytes: insights into the development of cell-based pacemakers. Circulation 111: 11-20, 2005.

154. Yamanaka S. A fresh look at iPS cells. Cell 137: 13-17, 2009.

155. Yang L, Soonpaa MH, Adler ED, Roepke TK, Kattman SJ, Kennedy M, Henckaerts E, Bonham K, Abbott GW, Linden RM, Field LJ, and Keller GM. Human cardiovascular progenitor cells develop from a KDR+ embryonic-stem-cellderived population. Nature 453: 524-528, 2008.

156. Yu J, Vodyanik MA, Smuga-Otto K, Antosiewicz-Bourget J, Frane JL, Tian S, Nie J, Jonsdottir GA, Ruotti V, Stewart R, Slukvin II, and Thomson JA. Induced pluripotent stem cell lines derived from human somatic cells. Science 318: 19171920, 2007.

157. Zeng L, Hu Q, Wang X, Mansoor A, Lee J, Feygin J, Zhang G, Suntharalingam P, Boozer S, Mhashilkar A, Panetta CJ, Swingen C, Deans R, From AH, Bache RJ, Verfaillie CM, and Zhang J. Bioenergetic and functional consequences of bone marrow-derived multipotent progenitor cell transplantation in hearts with postinfarction left ventricular remodeling. Circulation 115: 1866-1875, 2007.

158. Zhang J, Wilson GF, Soerens AG, Koonce CH, Yu J, Palecek SP, Thomson JA, and Kamp TJ. Functional cardiomyocytes derived from human induced pluripotent stem cells. Circ Res 104: e30-e41, 2009.

159. Zhou H, Wu S, Joo JY, Zhu S, Han DW, Lin T, Trauger S, Bien G, Yao S, Zhu Y, Siuzdak G, Scholer HR, Duan L, and Ding S. Generation of induced pluripotent stem cells using recombinant proteins. Cell Stem Cell 4: 381-384, 2009. 
160. Zimmet JM and Hare JM. Emerging role for bone marrow derived mesenchymal stem cells in myocardial regenerative therapy. Basic Res Cardiol 100: 471-481, 2005.

161. Zwi L, Caspi O, Arbel G, Huber I, Gepstein A, Park IH, and Gepstein L. Cardiomyocyte differentiation of human induced pluripotent stem cells. Circulation 120: 1513-1523, 2009.

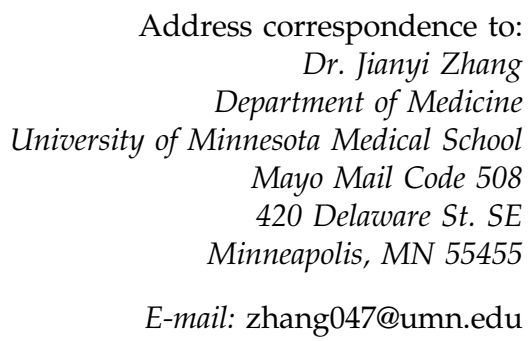

Date of first submission to ARS Central, June 28, 2010; date of final revised submission, August 3, 2010; date of acceptance, August 5, 2010.

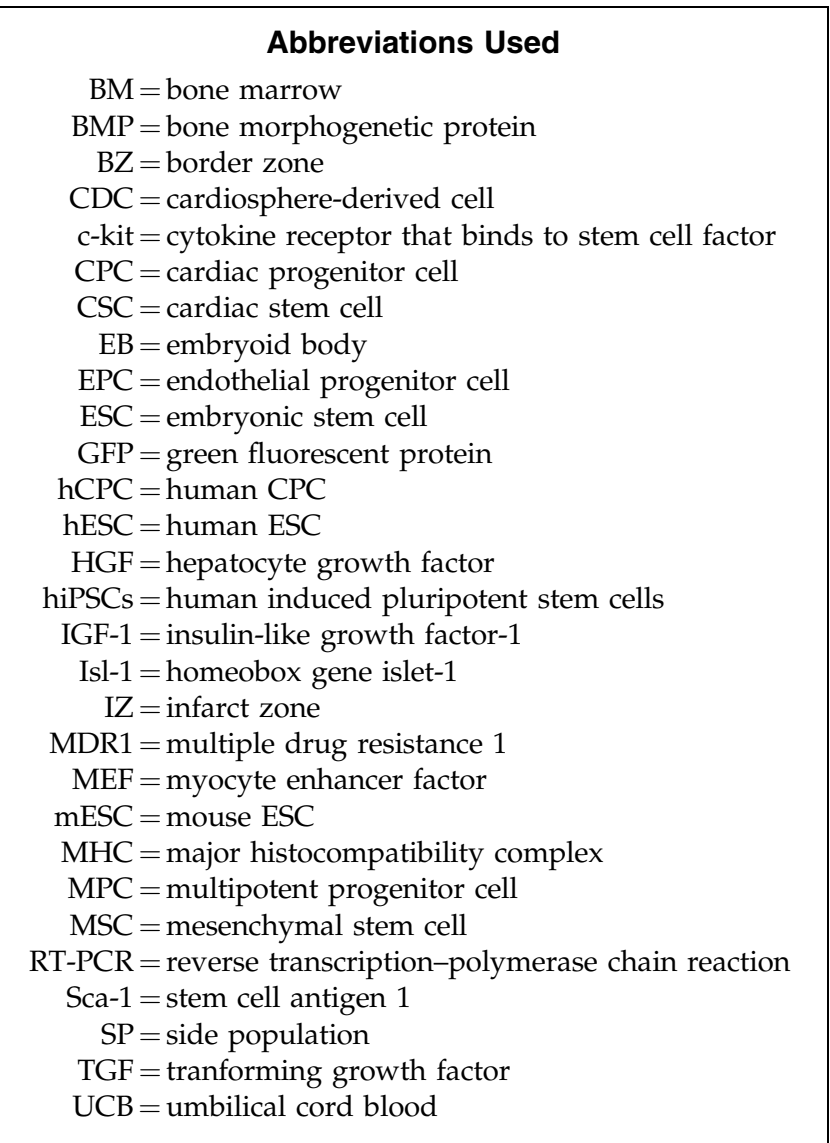


